Prepared in cooperation with the

U.S. Department of Homeland Security

Federal Emergency Management Agency

\title{
Elevation of the March-April 2010 Flood High Water in Selected River Reaches in Central and Eastern Massachusetts
}

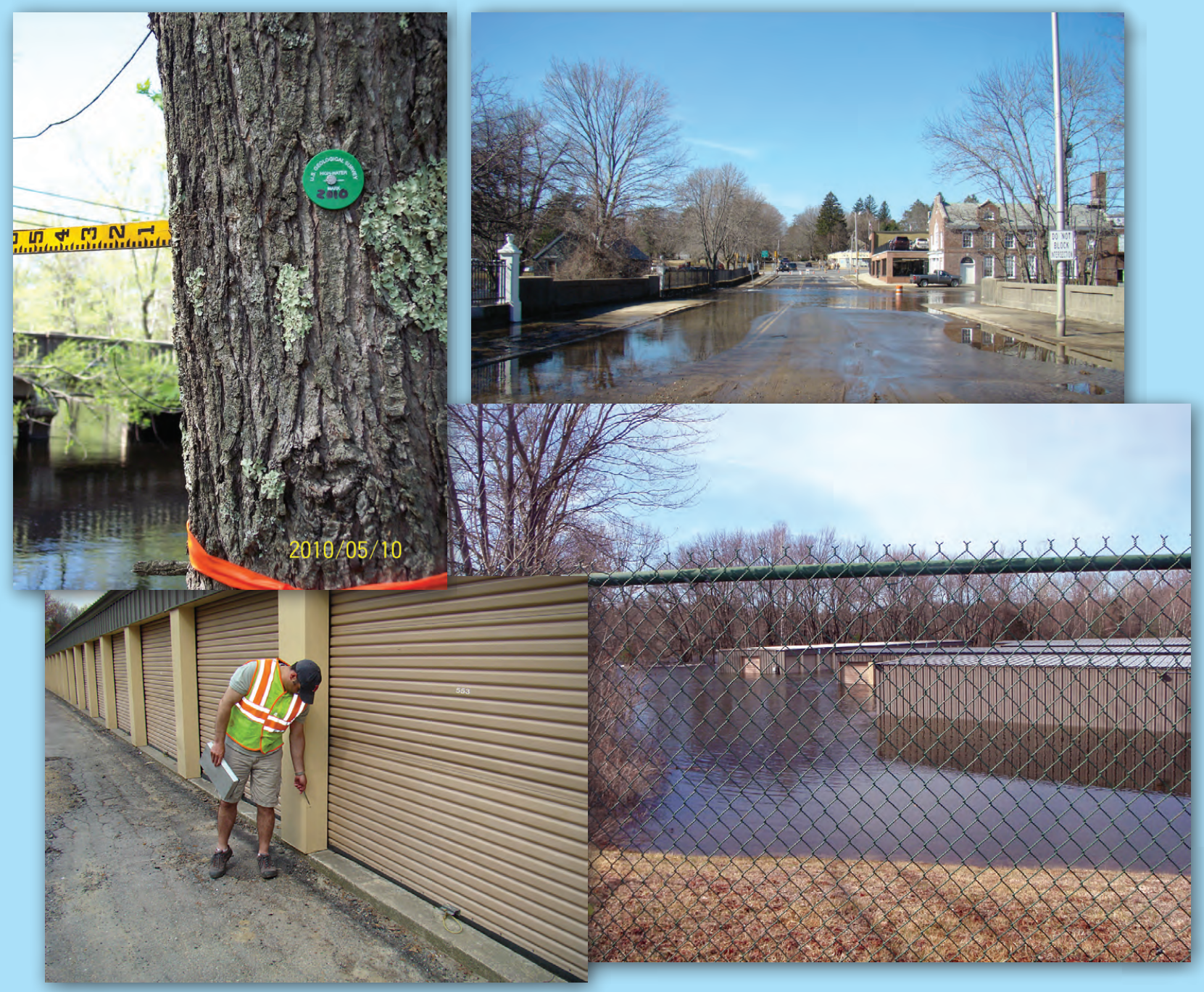

Open-File Report 2010-1315 



\section{Elevation of the March-April 2010 Flood High Water in Selected River Reaches in Central and Eastern Massachusetts}

By Phillip J. Zarriello and Gardner C. Bent

Prepared in cooperation with the

U.S. Department of Homeland Security

Federal Emergency Management Agency

Open-File Report 2010-1315 


\title{
U.S. Department of the Interior \\ KEN SALAZAR, Secretary \\ U.S. Geological Survey \\ Marcia K. McNutt, Director
}

\author{
U.S. Geological Survey, Reston, Virginia: 2011
}

For more information on the USGS - the Federal source for science about the Earth, its natural and living resources, natural hazards, and the environment, visit http://www.usgs.gov or call 1-888-ASK-USGS

For an overview of USGS information products, including maps, imagery, and publications, visit http://www.usgs.gov/pubprod

To order this and other USGS information products, visit http://store.usgs.gov

Any use of trade, product, or firm names is for descriptive purposes only and does not imply endorsement by the U.S. Government.

Although this report is in the public domain, permission must be secured from the individual copyright owners to reproduce any copyrighted materials contained within this report.

Suggested citation:

Zarriello, P.J., and Bent, G.C., 2011, Elevation of the March-April 2010 flood high water in selected river reaches in central and eastern Massachusetts: U.S. Geological Survey Open-File Report 2010-1315, 36 p. 


\section{Contents}

Abstract
Introduction
Purpose and Scope
Study Area
Rainfall and Antecedent Conditions
Streamflows
Sethods
Summary of High-Water Marks Identified High-Water Marks
Summary.
Acknowledgal Use of High-Water Data
References Cited.
Appendix 1. High-water marks identified by the U.S. Geological Survey and the
Massachusetts Department of Conservation and Recreation

\section{Figures}

1. Map showing river basins where high-water elevations were determined following the March-April 2010 floods in central and eastern Massachusetts.

2. Map showing total rainfall during February and March 2010 in southeastern New England .....

3. Daily rainfall $(A)$ hyetographs and $(B)$ cumulative totals during February and March 2010 at four National Weather Service (NWS) stations in central and eastern Massachusetts.

4. Hydrographs showing period-of-record daily mean flow percentiles and 2010 daily mean flow at $(A)$ Charles River at Dover (01103500) and $(B)$ Taunton River near Bridgewater (01108000), Massachusetts

5. Photographs showing examples of high-water mark debris lines on trees and structures found following the March-April 2010 floods in central and eastern Massachusetts.

6. Map showing fixed-based station Global Positioning System receiver network and National Geodetic Survey bench-mark control points used in the determination of the elevation of the March-April 2010 flood high water in central and eastern Massachusetts.

7. Map showing areas of availability of Llght Detection and Ranging (LIDAR) data and projected 2011 LIDAR data in Massachusetts and adjacent states 


\section{Tables}

1. Summary of March-April 2010 flood peak stage and flow data at selected U.S. Geological Survey streamgages in central and eastern Massachusetts..........................6

2. Summary of Global Positioning System (GPS) measurements made to National Geodetic Survey (NGS) bench marks...

3. Summary of high-water marks (HWMs) established by the U.S. Geological Survey (USGS) and the Massachusetts Department of Conservation and Recreation (MADCR) following the March-April 2010 floods in central and eastern Massachusetts

\section{Conversion Factors}

\begin{tabular}{|c|c|c|}
\hline Multiply & By & To obtain \\
\hline \multicolumn{3}{|c|}{ Length } \\
\hline inch (in.) & 25.4 & millimeter $(\mathrm{mm})$ \\
\hline foot (ft) & 0.3048 & meter $(\mathrm{m})$ \\
\hline mile (mi) & 1.609 & kilometer $(\mathrm{km})$ \\
\hline \multicolumn{3}{|c|}{ Area } \\
\hline square mile $\left(\mathrm{mi}^{2}\right)$ & 259.0 & hectare (ha) \\
\hline square mile $\left(\mathrm{mi}^{2}\right)$ & 2.590 & square kilometer $\left(\mathrm{km}^{2}\right)$ \\
\hline \multicolumn{3}{|c|}{ Flow rate } \\
\hline cubic foot per second $\left(\mathrm{ft}^{3} / \mathrm{s}\right)$ & 0.02832 & cubic meter per second $\left(\mathrm{m}^{3} / \mathrm{s}\right)$ \\
\hline
\end{tabular}

Vertical coordinate information is referenced to the North American Vertical Datum of 1988 (NAVD 88).

Horizontal coordinate information is referenced to the North American Datum of 1983 (NAD 83).

Elevation, as used in this report, refers to distance above the vertical datum. 


\title{
Elevation of the March-April 2010 Flood High Water in Selected River Reaches in Central and Eastern Massachusetts
}

\author{
By Phillip J. Zarriello and Gardner C. Bent
}

\section{Abstract}

A series of widespread, large, low-pressure systems in southern New England in late February through late March 2010 resulted in record, or near record, rainfall and runoff. The total rainfall in the region during this period ranged from about 17 to 25 inches, which coupled with seasonal low evaporation, resulted in record or near record peak flows at 13 of 37 streamgages in central and eastern Massachusetts. The highest record peaks generally occurred in southeastern Massachusetts in late March-early April; at most other streamgages, the peak was in mid-March.

Determination of the flood-peak high-water elevation is a critical part of the recovery operations and post-flood analysis for improving future flood-hazard maps and floodmanagement practices. High-water marks (HWMs) were identified by the U.S. Geological Survey (USGS) from April 13 through May 10, 2010, and by a consultant for Massachusetts Department of Conservation and Recreation (MADCR) after peak flows in mid-March and again in late March-early April. HWMs were identified at 25 river reaches in 7 designated Massachusetts Executive Office of Energy and Environmental Affairs (EEA) basins by the USGS and at 8 river reaches in 2 designated EEA basins by MADCR. The USGS identified 293 HWMs at 152 sites. A site may have more than one HWM, typically upstream and downstream from a bridge. The MADCR identified 133 HWMs; of these, 98 are at unique locations, and 29 of the 133 HWMs were visited once following the mid-March peak and again following the late March peak. The HWMs identified by the USGS and MADCR covered about 300 river miles, determined from the upstream and downstream HWMs (about 230 and 70 river miles, respectively). Elevation of HWMs was later determined to a standard vertical datum (NAVD 88) using the Global Navigation Satellite System and survey grade Global Positioning System (GPS) receivers along with standard optical surveying equipment.

\section{Introduction}

Flood flows and water levels set, or nearly set, record highs in mid- and late March into early April 2010 following repeated storms. In the wake of the severe flooding, a state of emergency was declared in many communities in central and eastern Massachusetts, and a Presidential Disaster was declared on March 29, 2010. The President's action affected the emergency recovery operations in Bristol, Essex, Middlesex, Norfolk, Plymouth, Suffolk, and Worcester Counties. Federal assistance for storm-related damages from this disaster totaled more than $\$ 100$ million on August 17, 2010 (FEMA, 2010). As part of the recovery operations, the U.S. Department of Homeland Security's Federal Emergency Management Agency (FEMA) required analysis of the flood to assess damages and to prepare for and minimize future flood damages.

Determination of the peak high-water elevation is a critical part of the recovery operations and post-flood analysis. This information also is extremely valuable when defining and understanding flood risks for flood management. FEMA entered into an agreement with the USGS on April 29, 2010, to identify high-water marks (HWMs) in selected river reaches in Massachusetts in the counties affected by the disaster declaration. A subsequent agreement between FEMA and the USGS was signed in June 2010 to survey and document the HWMs identified from the March-April 2010 floods to support future analysis for flood-mitigation efforts.

\section{Purpose and Scope}

The purpose of this report is to document the elevation of peak high water following the March-April 2010 floods in central and eastern Massachusetts. The report describes the conditions prior to the flood, recorded gage heights and flows at USGS streamgages, methods used to identify high-water marks, and the surveying methods used to obtain a vertical 
datum of the high-water mark. The report summarizes the HWM data for selected river reaches and presents data in tables and figures.

\section{Study Area}

High-water elevations of the March-April 2010 floods were documented mostly for rivers in the eastern part of Massachusetts where flooding was the most severe (fig. 1); elevations are also documented for several basins in the central part of the State. The following Massachusetts Executive Office of Environmental and Energy Affairs (EEA) planning basins were included in this study: Taunton, Ten Mile, South Coastal, Boston Harbor, Charles, SuAsCo (Sudbury, Assabet, and Concord River Basins), Nashua, Millers, North Coastal, and Ipswich Basins.

\section{Rainfall and Antecedent Conditions}

A series of widespread, large, low-pressure systems passed through the New England region in late February and in mid- through late March 2010 resulted in record, or near record, amounts of rainfall. During March, the total rainfall at Logan International Airport in Boston was the second highest recorded (14.83 in.) since 1872; the highest total rainfall of record (18.81 in.) recorded at Blue Hill Observatory southeast of Boston since in 1885 (National Weather Service stations 190770 and 190736, respectively; fig. 2). The highest monthly total rainfall recorded in Boston (17.09 in.) was in August 1955 that resulted from tropical hurricanes Connie and Dianne (U.S. Department of Commerce, 1955).

During a period when evaporation losses are normally low, these low-pressure systems maintained wet soil moisture conditions and filled available surface storages that resulted in record, or near record, floods in southern New England. The Northeast Regional Climate Center (2010) March Climate Summary report described the following conditions: "The mid-March storm hit the region from March 13-15, dropping as much as 9 inches of rain in eastern Massachusetts. As floodwaters began to recede an additional 2 to 5 inches of rain fell on March 22nd and 23rd, followed by 5 to 9 inches of rain on the 29th and 30th."

Rainfall hyetographs and cumulative rainfall (fig. 3A and 3B) for four selected National Weather Service (NWS) daily record stations (190840, 193890, 194760, and 195524; fig. 2) exemplify the pattern of excessive moisture in eastern Massachusetts. Prior to the March high water, a late February storm dropped nearly 5 inches of rain over the region, saturating soils, filling available storage, and elevating streamflows. Thus, conditions were primed for the first large runoff response following the 4 to 9 inches of rain that fell between March 13th and 15th. From late February through mid-March total precipitation ranged from about 9 to 15 inches in the study area, resulting in the maximum peak stages and flows at streamgages in the region that set new record peaks at some stations. As flood waters began to recede, rainfall on March 22-23 amounted to an additional 2 to 5 inches, which maintained wet conditions and elevated streamflows in the region. Wet conditions continued through late March with another large pulse of rain on the 29th and 30th. The new rains resulted in peak stream stages and flows that exceeded the mid-March stages and flows at 11 streamgages depending on the rainfall intensity and totals. Overall, the total rainfall at four NWS stations (fig. 3) ranged from about 17 to 22 inches since late February through March, which is unprecedented in the past 100-year weather history, especially during the cool season when moisture losses to evaporation are low. The total rainfall during February and March 2010 over eastern Massachusetts and surrounding states (fig. 2) indicates the highest amounts occurred from Narragansett Bay northward along the southern New England coast. The area of high rainfall in northeastern Massachusetts and northward was about equal to the total rainfall in southeastern Massachusetts and Rhode Island, but northeastern Massachusetts had less severe flooding than southeastern Massachusetts. Less severe flooding in northeastern Massachusetts resulted because a greater portion of the total rainfall in this region was in late February when water storage was more available.

\section{Streamflows}

Peak stages and flows recorded at USGS streamgages in central and eastern Massachusetts (table 1) indicate the magnitude of the March-April 2010 flood relative to the magnitude of past floods over the period of the streamgage record. The 2010 stage and flow data are provisional until the entire segment of streamflow record is analyzed and approved. Waiting for the approval of streamflow data would cause undue delays for this report. Approval of the data was not considered necessary for the primary objective of documenting the elevation of the flood high water. However, the data on peak stage and flow were reviewed and are considered to be in good condition for use in this report.

Of the 37 streamgages listed in table 1, new peak stage and flow records were set at 13 streamgages following the March-April 2010 floods. The average increase in peak flows from the previous peak of record at the 13 streamgages was about 10 percent; the maximum increase in peak flow was at Quniapoxet River at Canada Mills near Holden (01095375), which was 31 percent greater than the previous peak recorded in March 1998. Peak flows at three streamgages were within about 10 percent of the previous record peak. Peak flows at 24 streamgages during March-April 2010 did not exceed the previous peaks of record; the average March-April peak flows at these streamgages were about 28 percent less than the previous peaks of record. In general, the previous peaks of record were greater than the March-April 2010 peaks for streamgages in the western and central parts of the study area to the west, particularly for streamgages that included floods of 1936, 1938, and 1955. 


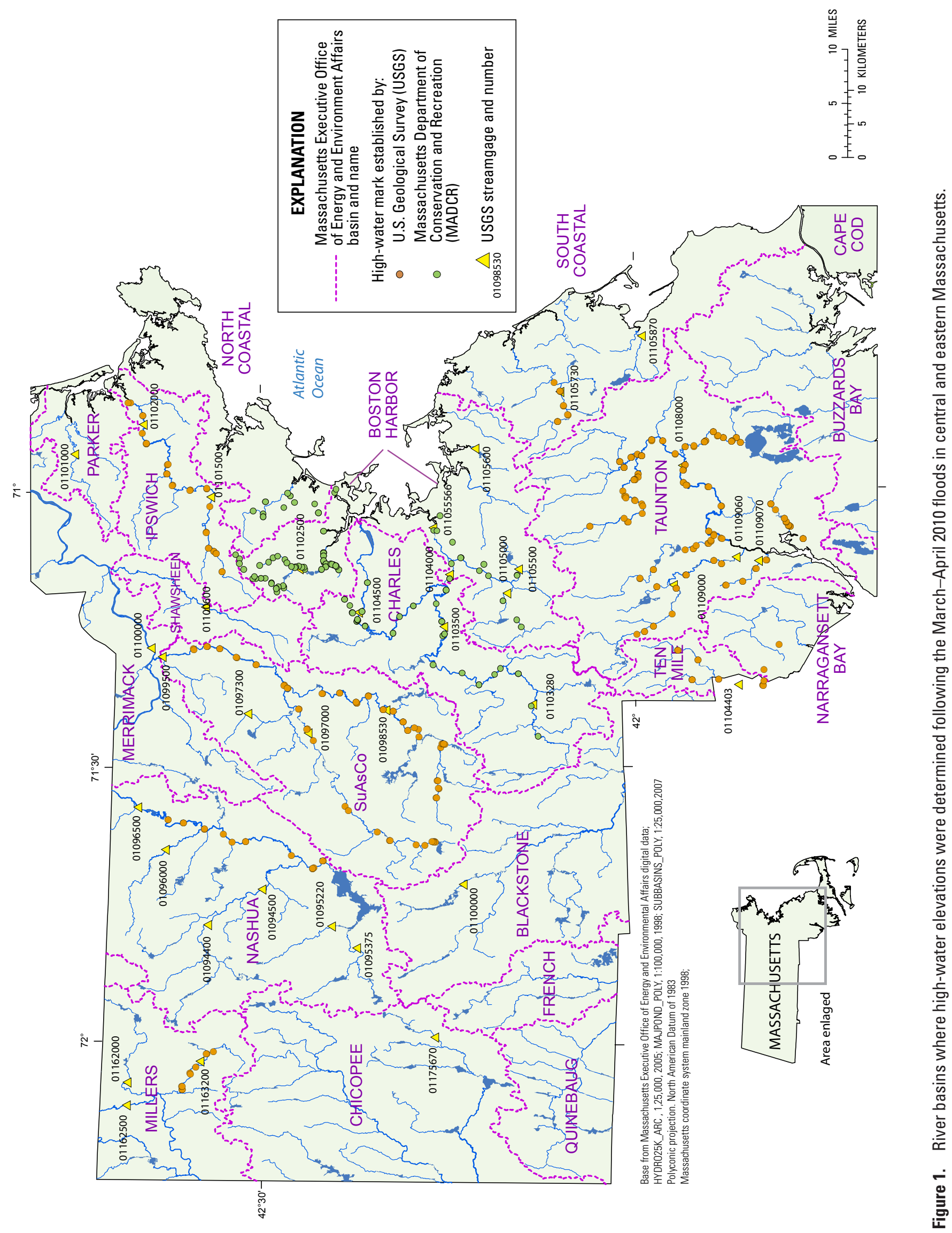




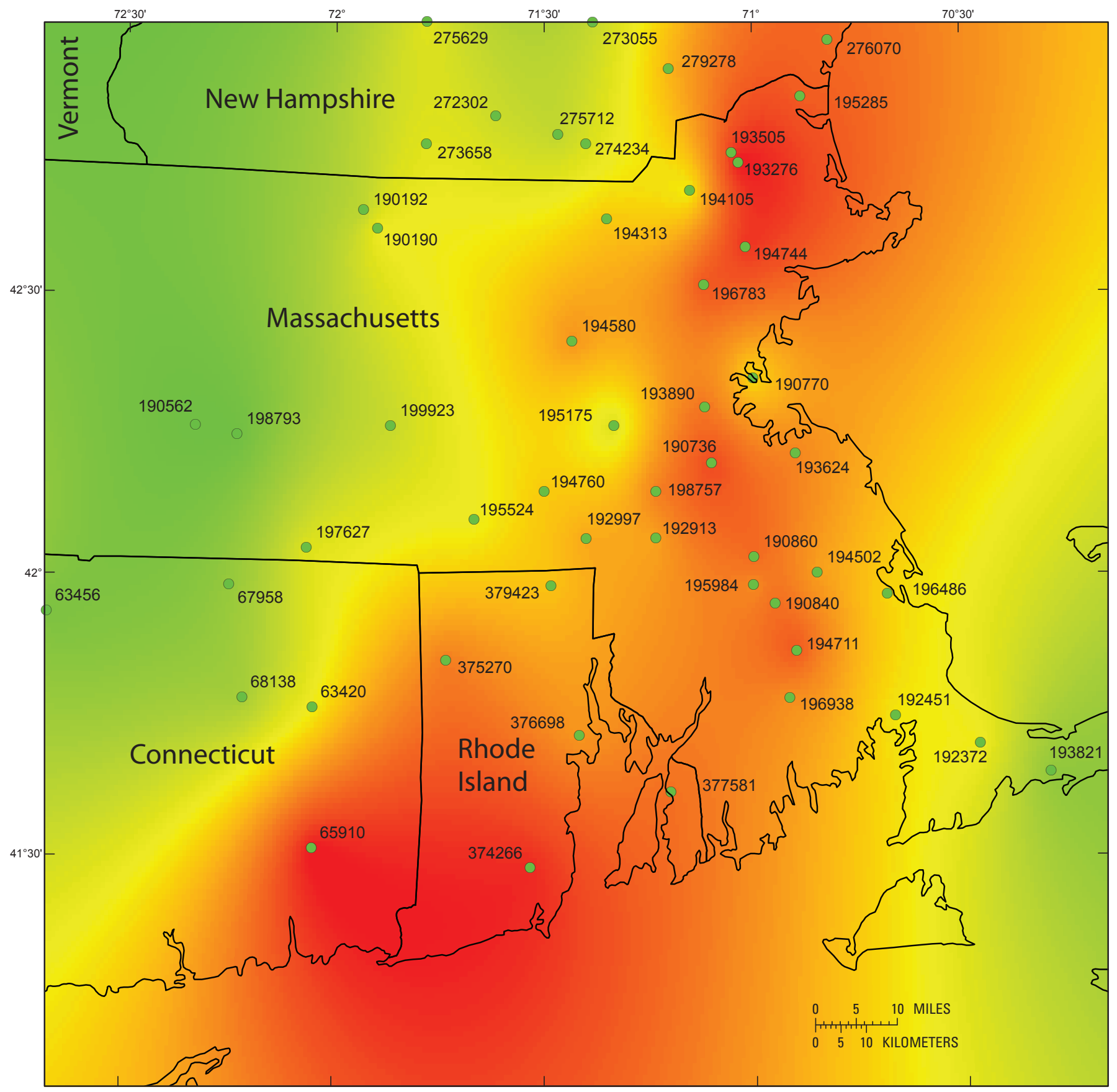

\section{EXPLANATION}

Precipitation, in inches

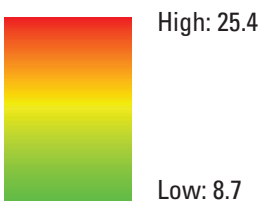

$376698^{\bigcirc}$ National Weather Service Station and identification number (COOPID)

Total rainfall map created by linear radial interpolation with constant trending of point data from National Weather Service stations. Note some of the stations used are outside the map extent.

Figure 2. Total rainfall during February and March 2010 in southeastern New England. 


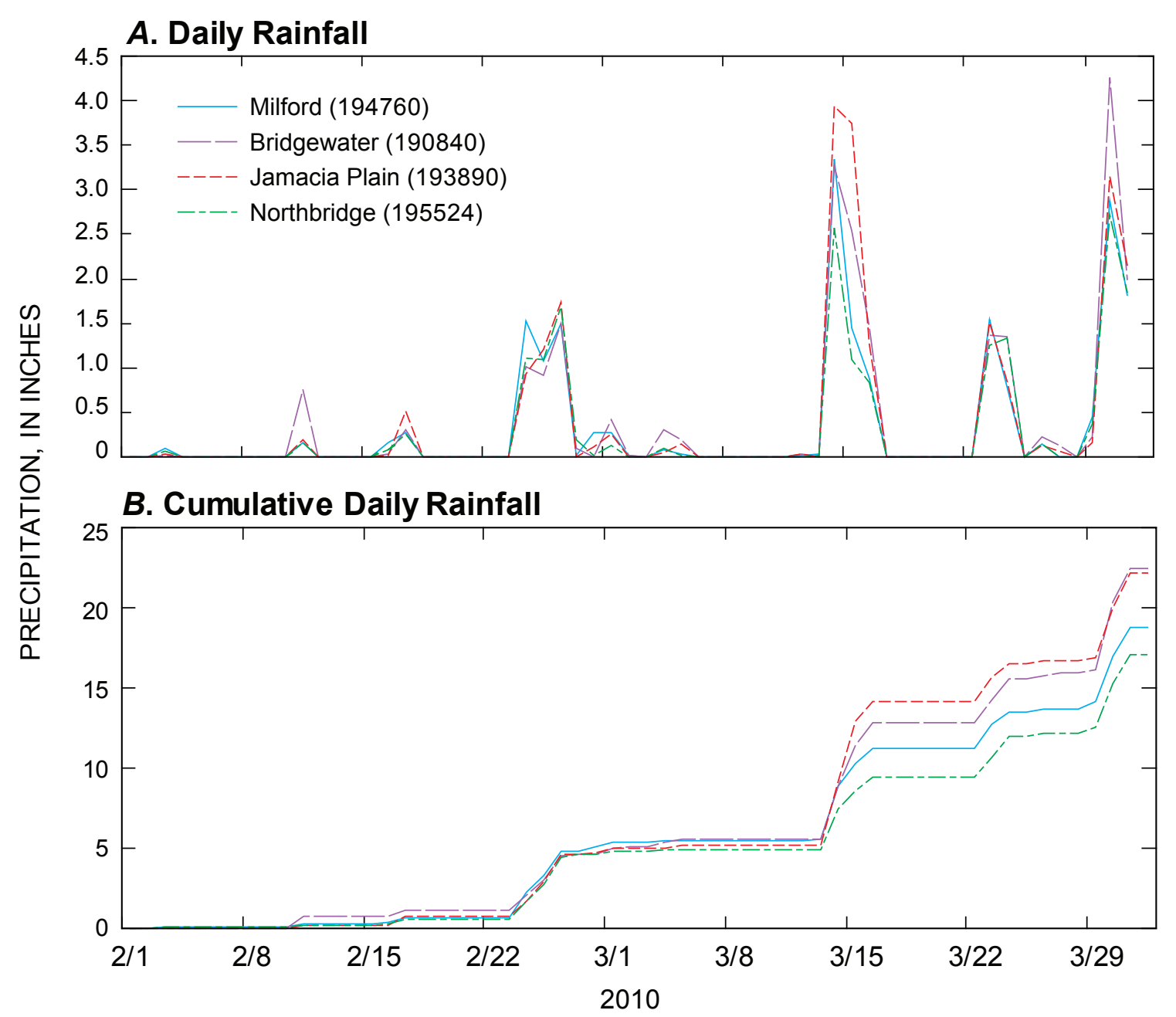

Figure 3. Daily rainfall $(A)$ hyetographs and $(B)$ cumulative totals during February and March 2010 at four National Weather Service (NWS) stations in central and eastern Massachusetts. Number in parenthesis is the NWS station shown in figure 2. 


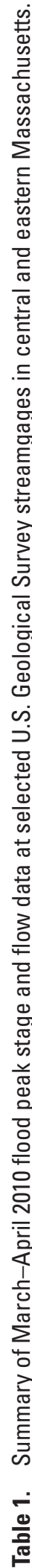

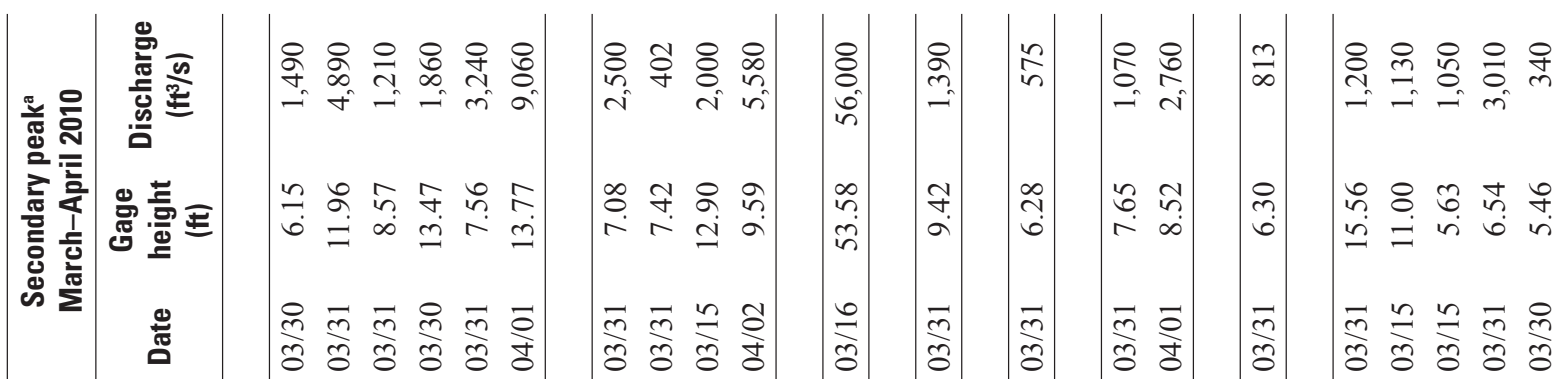

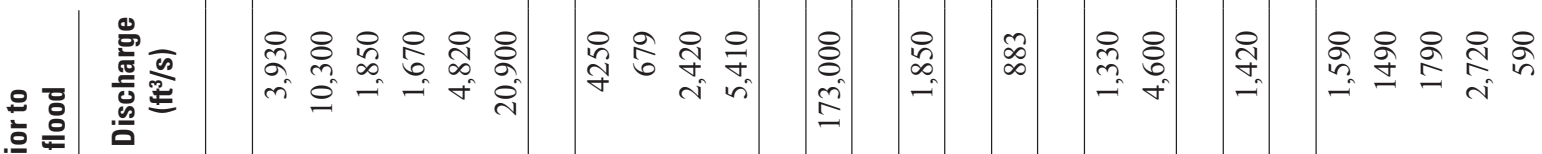

는 웅

츨 웅 흠

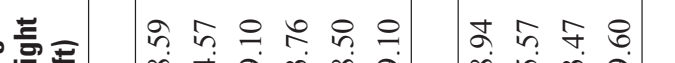

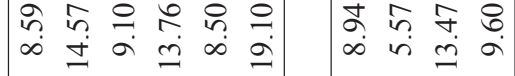

总亭

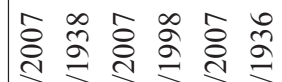

告

তิ

ì

文

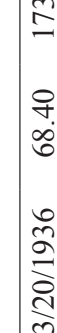

ఫ

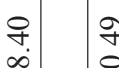

$\stackrel{\substack{a \\ \dot{0}}}{\operatorname{ran}}$

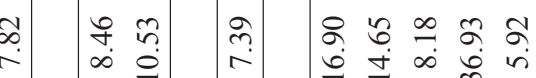

$\overline{0}$

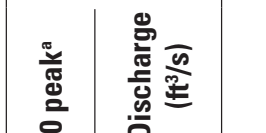

응 \&

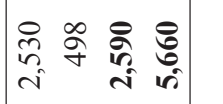

ஓ.

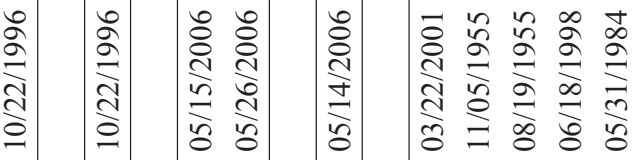

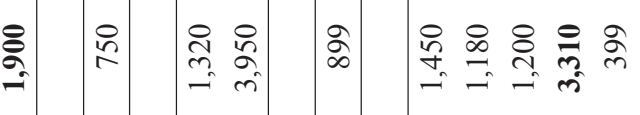

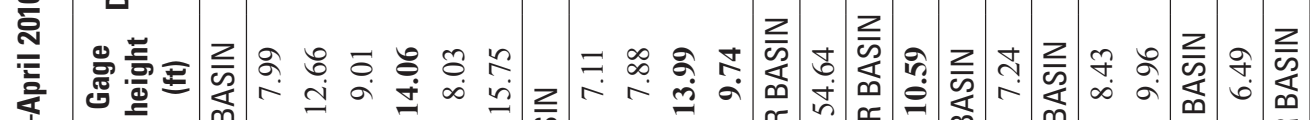

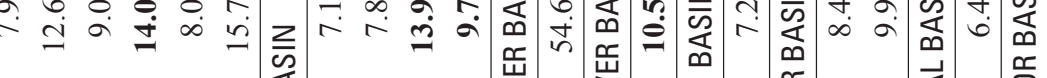

वे

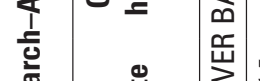

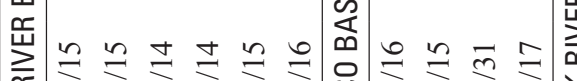

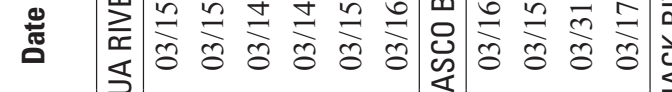

$\overrightarrow{\frac{1}{c}}$

舀

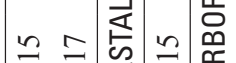

으요 0

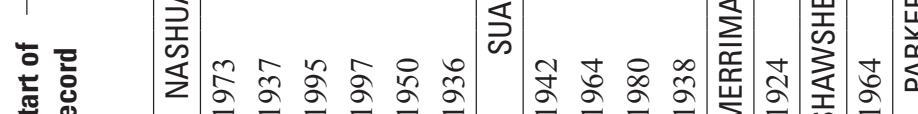

के 인

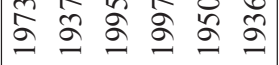

천

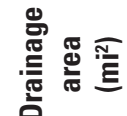

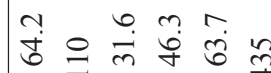

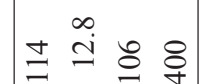

n

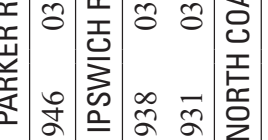

퐁음

$\frac{m}{\infty} \frac{m}{\infty} \frac{\pi}{0} \frac{\pi}{0}$
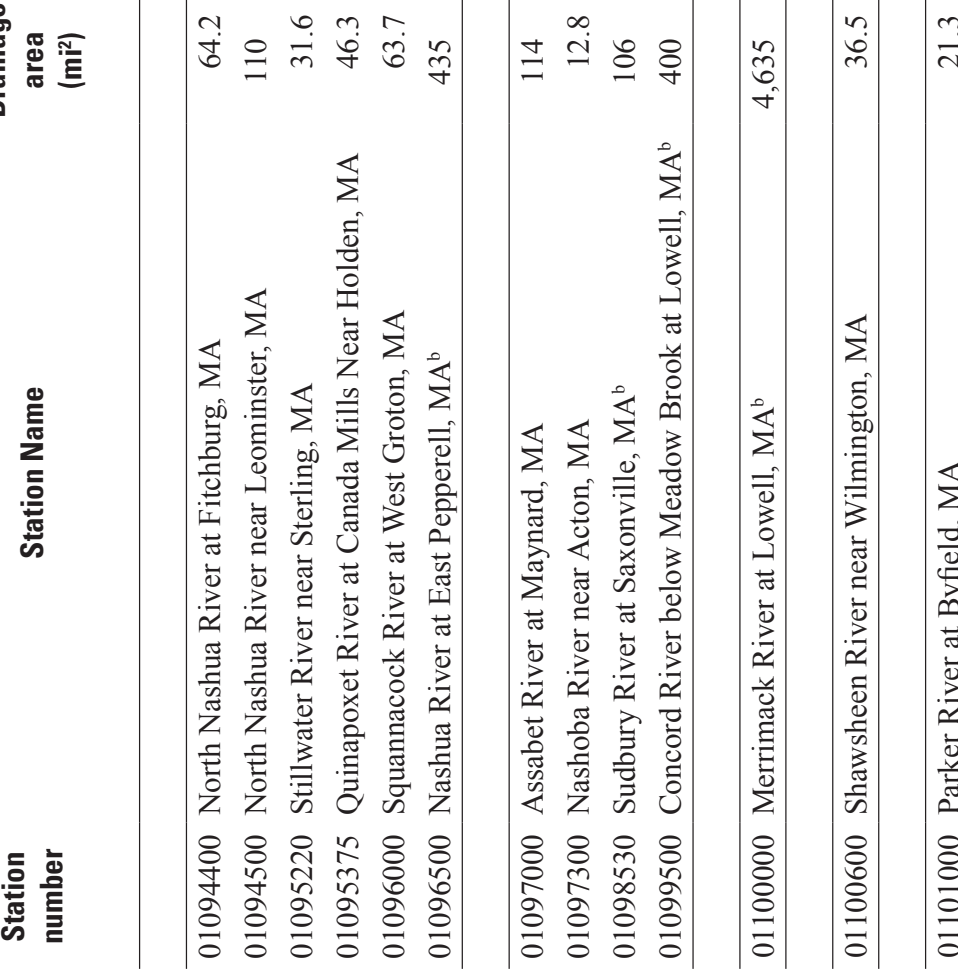

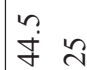

웡

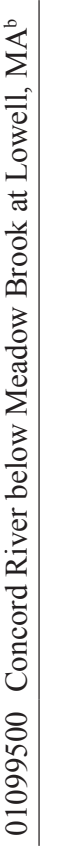
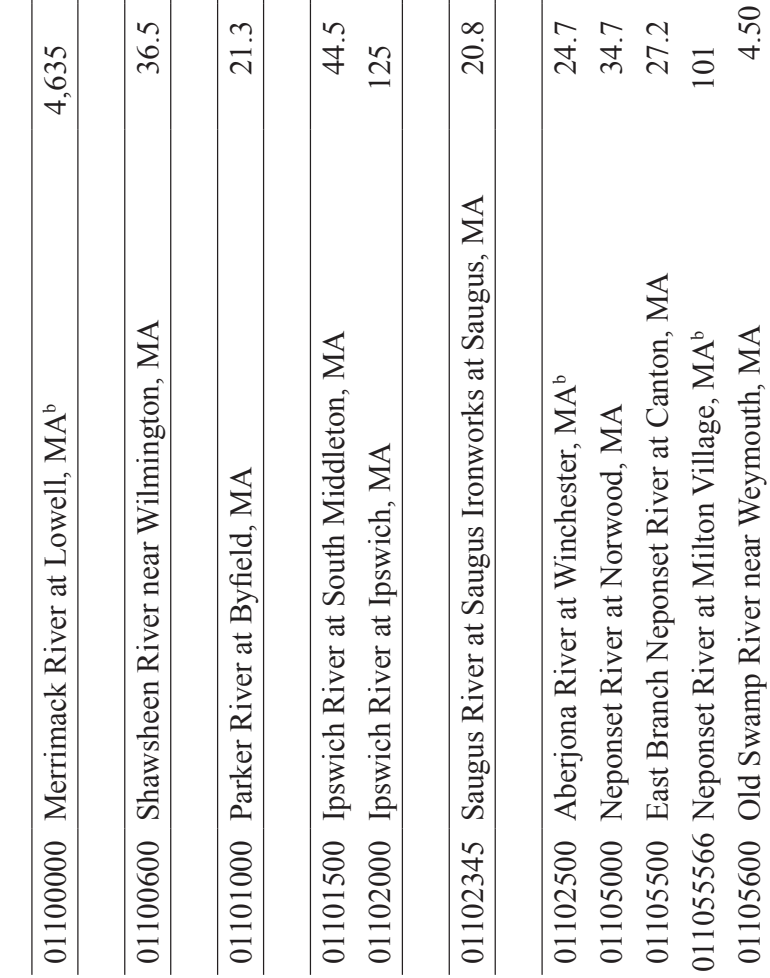


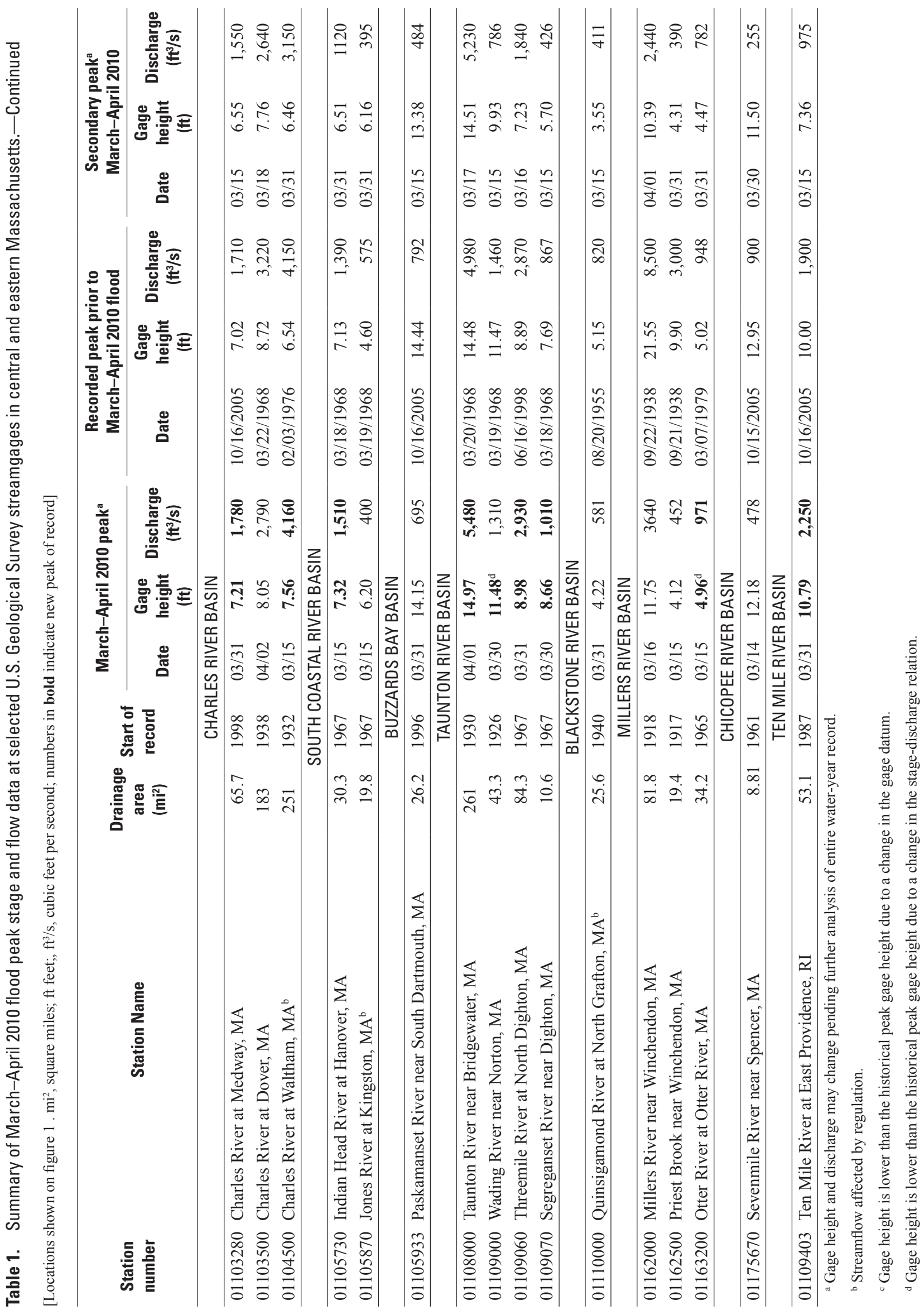


Flow conditions in the region prior the March floods are illustrated by the daily mean flow for the 2010 water year in relation to the 10th-, 25th-, 50th-, 75th-, and 90th-percentile flows for a given day, calculated from the period-of-record daily mean flows at Charles River at Dover (01103500) and Taunton River near Bridgewater (01108000) (fig. 4A and 4B, respectively). Note that these streamgages were established in 1938 and 1930, respectively. Prior to the late February rainfall, flows were below the median (50th percentile) but quickly rose well above the 90th percentile following the late February rainfall. Flows that exceeded the 90th percentile occurred only 10 percent of the time at this time of year, which is the normal seasonal high-flow period. Flows receded to about the median range in early March, then rose sharply following the mid-March storm to set a new peak flow for water year 2010 . Flows continued to stay above the 90th percentile into late March because of saturated conditions and additional rainfall. Another large rainfall event at the end of March caused a rise in streamflow that slightly exceeded the peak flow in midMarch at the Charles River at Dover (01103500) and Taunton River near Bridgewater (01108000) streamgages. Again, note that at 24 of the 37 streamgages in table 1, the mid-March peak flows exceeded the late March-early April peak flows.

Streamgages in southeastern Massachusetts indicate that the highest peak stages and flows during the 2010 floods generally occurred in late March-early April (table 1); these included streamgages in the Neponset River, except at Milton Village (011055566); in the Charles River, except at Waltham (01104500); and in Buzzards Bay, Taunton River, and Ten Mile River Basins. At the seven streamgages in these basins the median late March-early April peak flows were about 13 percent greater than the mid-March peak flows. The greatest differences in peak flows were in the lower Taunton and Ten Mile River Basins for Wading River (01109000), Threemile River (01109060), Segreganset River (01109070), and Ten Mile River (01109403), which had late March-early April peak flows that were about 40-, 37-, 58-, and 57-percent greater, respectively, than the mid-March peak flows. At most other streamgages reported in table 1, the primary 2010 peak occurred in mid-March. The mid-March peak flows were as little as 1 percent greater than the late March-early April peak flows in the Assabet and Concord River Basins, but the differences between the mid-March peaks and the late Marchearly April peaks generally increased to the west and north of southeastern Massachusetts. In rivers and streams where the mid-March peak stages were higher than the secondary peaks in late March-early April, the determination of the highest peak stage was less certain because evidence of the earlier peaks may have been destroyed.

\section{Methods}

HWMs are the evidence of the highest water levels during a flood (Benson and Dalrymple, 1967). There are many types of HWMs, but most are left by vegetative debris stranded at the highest water elevation. The best HWMs are small seeds or floating debris that adhere to smooth surfaces or lodge in tree bark that forms a distinct water line. Stain lines on buildings, fences, and other structures also provide excellent marks. HWMs are best identified immediately following the peak stage as time and weather (wind and rain) fade the evidence of the peak water line. Additionally, care was taken to identify HWMs farthest from the main channel as possible where velocities are generally small and pileup or drawdown's common in fast moving waters are best avoided. The general methods used to identify and document HWMs are described by Benson and Dalrymple (1967).

\section{Setting High-Water Marks}

USGS field crews consisted of at least one person experienced in identifying HWMs. Crews would identify HWMs and corroborating evidence of surrounding HWMs. The corroborating information became more important as the quality of the HWM decreased. After a satisfactory HWM was found, a more permanent identification mark was established, such as a disk, stake, chisel mark, or paint line (examples shown in fig. 5). Flagging, written descriptions, sketches, photos, and handheld Geographic Position System (GPS) horizontal position measurements were made so the marks could be found later and surveyed to a standard vertical datum or for other analysis, such as determination of the flood profile over the river reach.

Identification of HWMs by the USGS began on April 13 and continued through May 10, 2010. Four USGS field crews were mobilized to identify HWMs as soon as possible because of the significance of the flood and to minimize loss of time critical data. Note that high-water levels became more difficult and time consuming to identify, and the quality of the HWMs deteriorated with time. Field work was limited until an agreement was signed (April 29, 2010) and resources could be directed to this activity. As a result USGS field crews sometimes found two distinct high-water lines that likely resulted where the late March-early April peak was lower than the mid-March peak. The highest water-level evidence was used when establishing a HWM, but if the overall peak occurred in mid-March, evidence of that peak could have been erased by heavy rains that occurred later in the month.

The MADCR HWMs were identified by a consultant working under contract for MADCR. The MADCR HWMs were identified mostly at bridges and were marked by a wide paint line, which made the vertical position of the HWM uncertain when the marks were later surveyed to a standard vertical datum. Generally, the surveyor assumed the middle of the paint line was the vertical position of the HWM. In addition, most HWMs were located near the main channel, which also can cause uncertainty because of wave action, potential pileup of water against the upstream side of a bridge, and drawdown at the downstream of a bridge. The MADCR HWMs were identified shortly after peak flows in mid-March and in late-March to early-April. 


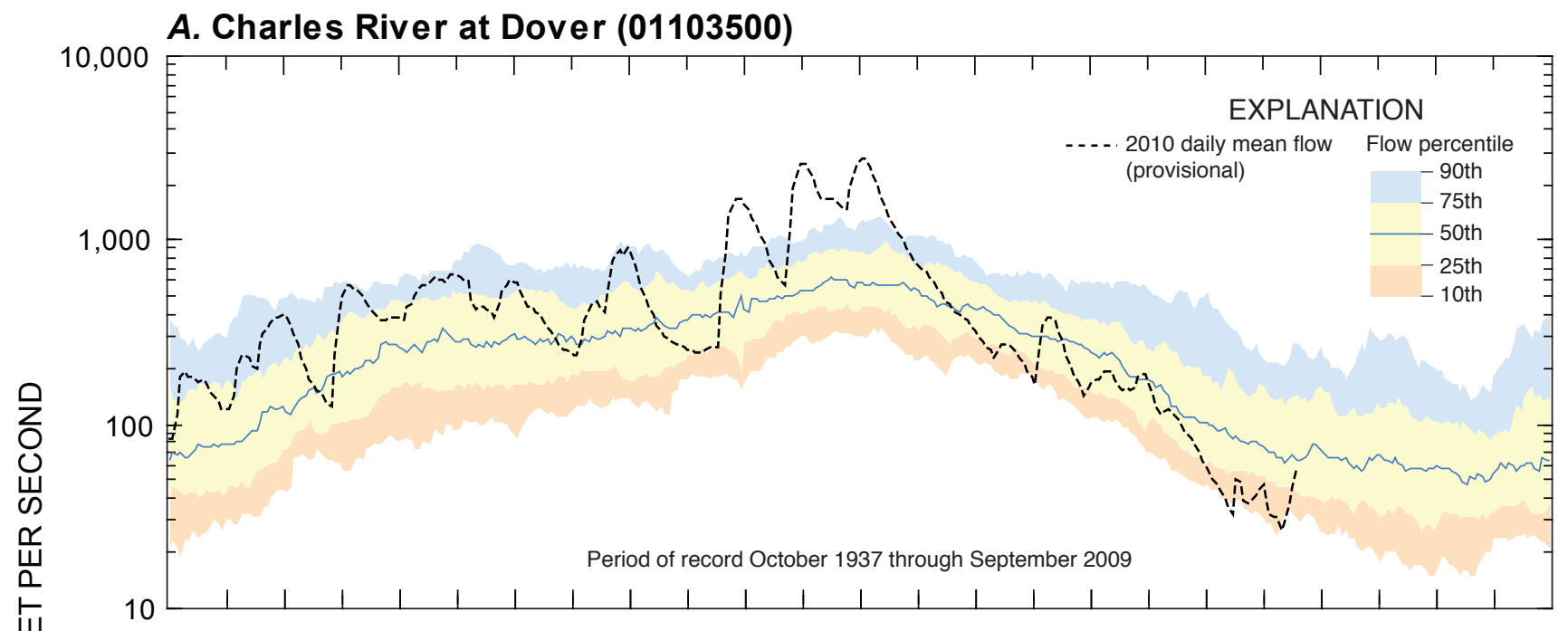

$\frac{0}{9}$

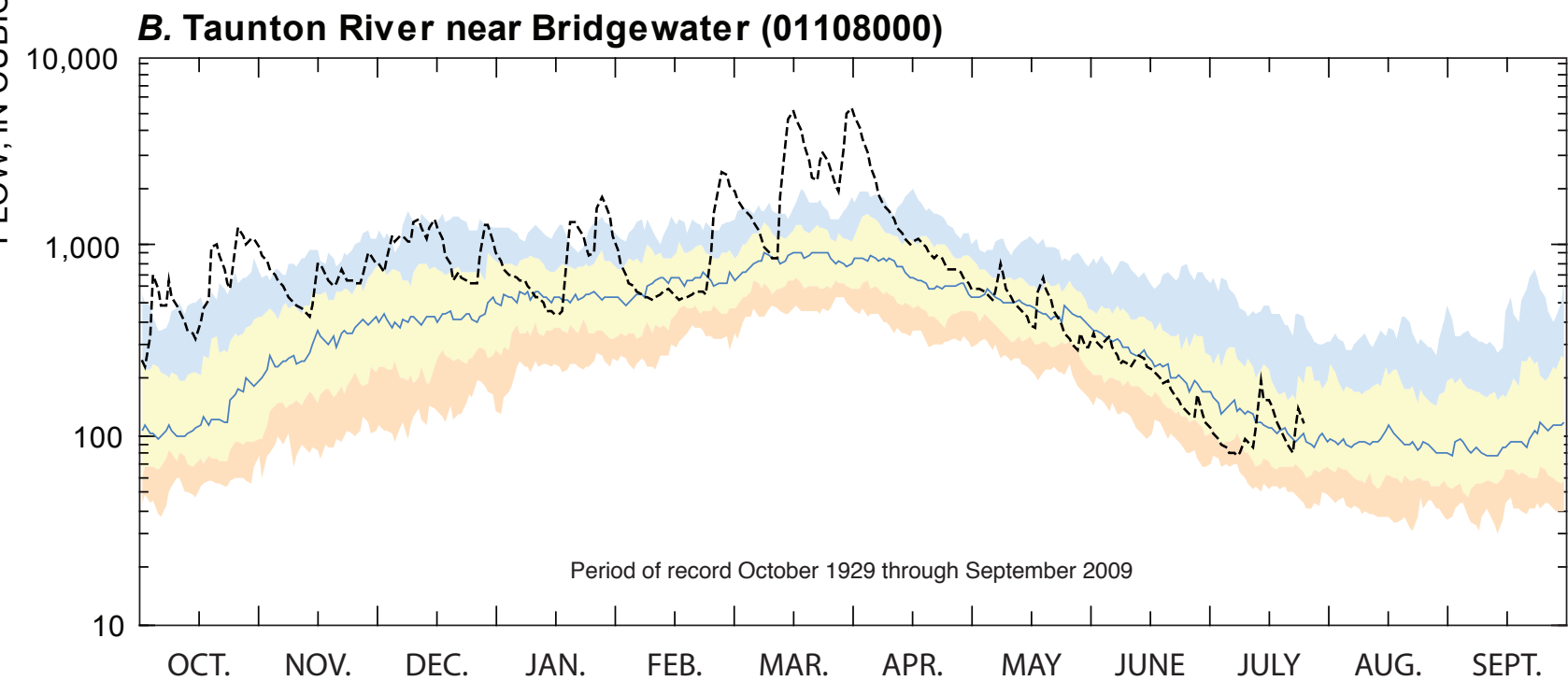

Figure 4. Period-of-record daily mean flow percentiles and 2010 daily mean flow at $(A)$ Charles River at Dover $(01103500)$ and $(B)$ Taunton River near Bridgewater (01108000), Massachusetts. Location shown in figure 1. 


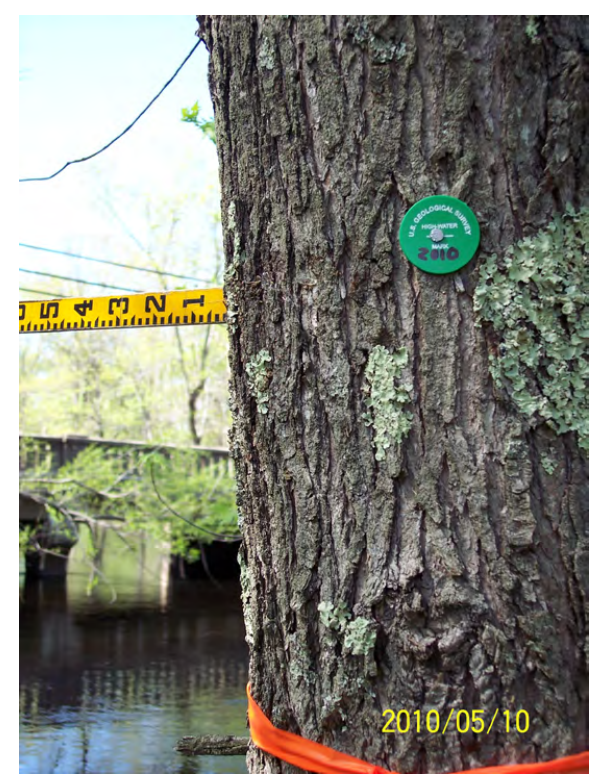

Ipswich River (IpsSR)

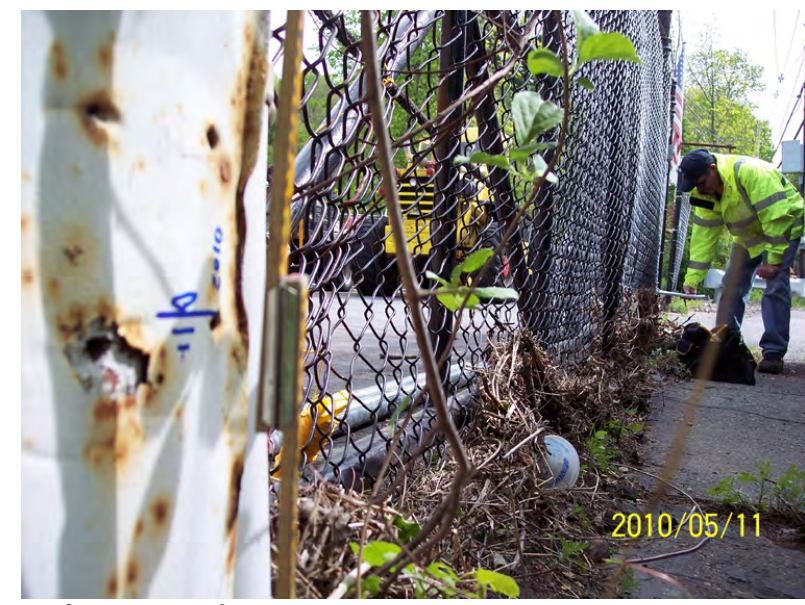

Indian Head River (IHRKS)

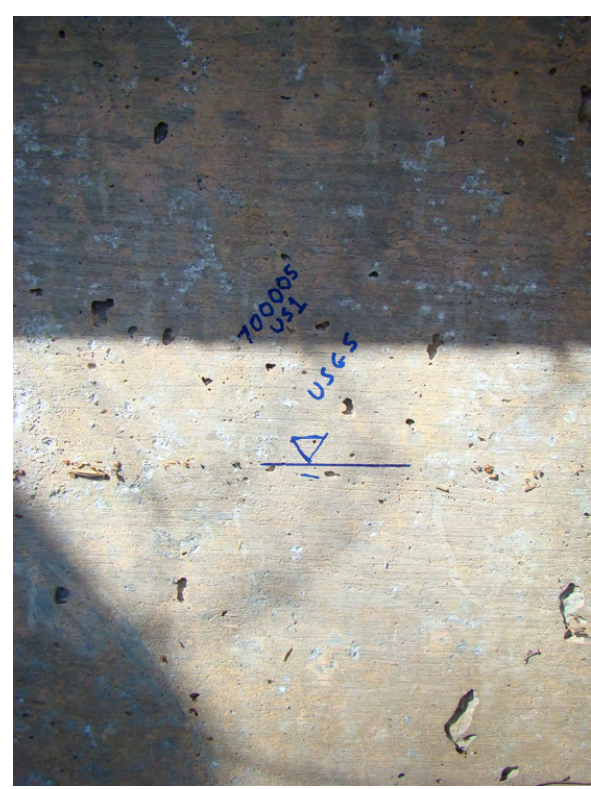

Assabet River (A700005)
Nashua River (A80000)

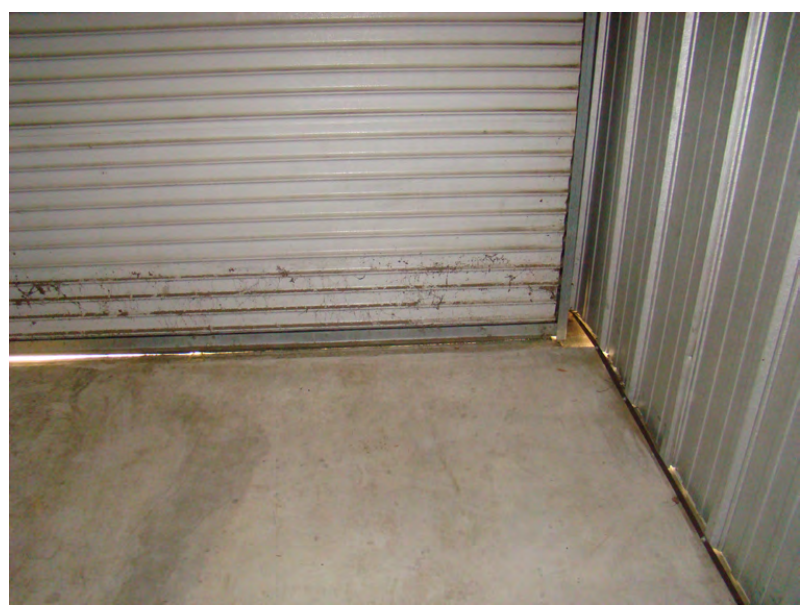

Nashua River (A8000)

Figure 5. Examples of high-water mark debris lines on trees and structures found following the March-April 2010 floods in central and eastern Massachusetts. Value in parentheses refers to the Site_ID in Appendix I, table 1-1. 


\section{Elevation of High-Water Marks}

Elevation of HWMs were later surveyed to a standard vertical datum (NAVD 88) using the Global Navigation Satellite System (GNSS) and survey grade GPS receivers along with standard optical surveying equipment. The GPS surveys were conducted using Trimble R8 receivers that support the L1 and L2 signals; two of the four receivers used also support GLONASS L2C and L5 signals. At each HWM site a temporary survey point (PK) was established in an open area to provide the best possible satellite reception. For each PK, the GPS receiver was initialized away from, and then leveled over the PK. This procedure was repeated by reinitializing the GPS unit (the receiver was flipped upside down for several seconds to lose the GPS signals) to obtain an independent reading. If the vertical elevation of the PK differed by more than about $0.10 \mathrm{ft}$, the procedure was repeated until an acceptable agreement was reached. Elevation of repeated PK measurements generally agreed to within $0.05 \mathrm{ft}$. Standard optical surveying equipment was used to tie the HWM to the PK elevation using a closed loop survey. Ninety-seven percent of the 339 loop surveys closed to within $0.01 \mathrm{ft}$ or less, 2 percent closed to within $0.02 \mathrm{ft}$, and two closed within $0.05 \mathrm{ft}$ and $0.11 \mathrm{ft}$.

Continuous real-time differential corrections to the GPS horizontal and vertical positions were made using a proprietary fixed-base station GPS network operated by KeyNetGPS, Inc. The network and associated software determine corrections for satellite signals received by the field GPS for ionosphere and other atmospheric disturbances recorded at three or more of the closest fixed-base stations relative to the position of the field GPS receiver. The fixed-base stations receivers continuously stream data to a central server that calculates corrections at the location of the field GPS receiver in real time. The field GPS controllers require at least version 12 GPS controller software to utilize the fixed network. The fixed-station network in the eastern Massachusetts region, nearest the HWMs, consists of seven stations near Keene (NHCK) and Derry (CPO1), NH; Boston (KP19), Fall River (ABL1), Fitchburg (FSC1), and Framingham (KP16), MA; and Providence (NBC1), RI. Quality-assurance GPS measurements were made at 27 National Geodetic Survey (NGS) bench marks (BMs) with vertical datum's throughout the study area (fig. 6). The elevation of the GPS measured BMs yielded a vertical root mean square error (RMSE) of $0.15 \mathrm{ft}$ (table 2) for 26 of the $27 \mathrm{BMs}$; one BM was not used because it appeared to have been reset (new construction), which is collaborated by the vertical difference of $0.78 \mathrm{ft}$. between the published and the GPS-determined elevation. The accuracy of the HWM survey meets the standards specified by FEMA (2003) in Guidelines and specifications for flood hazards mapping partners, Appendix A: Guidance for aerial mapping and surveying.

\section{Summary of High-Water Marks Identified}

High-water marks were identified following the MarchApril 2010 flood along 25 river reaches in 7 EEA designated basins by the USGS and in 8 river reaches in 2 EEA designated basins by MADCR (table 3 ). The USGS identified 293 HWMs at 152 sites (a site may have more than one HWM, typically a bridge crossing with HWMs identified on the upstream and downstream side of the bridge), which are listed in Appendix I, table 1-1. At seven of the sites listed in table 1-1, no HWM was set; note, the dataset does not consistently report all sites visited where no HWM was set. During the later GPS surveys, three of the USGS HWMs were destroyed, and two others could not be found. The MADCR identified 133 HWMs, which are listed in Appendix I, table 1-2. Of these, 98 are at unique locations; 29 of these were visited twice following the mid-March peak flows and again after the late-March peak flows. One HWM was identified in the GPS survey in the same general location where a HWM was previously identified. Multiple HWMs sighted by MADCR were not typically identified at the same location, such as upstream and downstream from a bridge, but multiple HWMs were identified separately following the mid- and late-March peak flows. During the later GPS survey, 11 of the MADCR HWMs could not be found. Six HWMs were found to have an elevation (NAVD88) below sea level and were found below the water surface at the time of the GPS survey; five of these were in the Mystic Basin.

The HWMs identified by the USGS and MADCR covered about 300 river miles, as determined from the upstream and downstream HWMs along river reaches; about 230 and 70 river miles were covered by USGS and MADCR, respectively. The density of HWMs per mile of river reach for USGS HWMs ranges from a lower quartile of about 1.0 to an upper quartile of about 1.6, with a median of $1.5 \mathrm{HWMs}$ per mile. The elevation of HWMs upstream from bridges were, on average, about $1.2 \mathrm{ft}$ higher than the downstream HWMs near the same bridge; in 27 out of $106 \mathrm{HWMs}$ at a bridge, the upstream elevation was lower than the downstream elevation (these sites were not included in the average elevation difference between upstream and downstream HWMs). HWMs that are higher downstream than upstream may be the result of a poor quality mark, which is often reflected in the rating of the HWM, but also could be attributed to different high-water peaks from mid- and late March, as previously noted. The density of HWMs identified by MADCR varied by storm; about 35 percent more HWMs were identified following the mid-March peak flows than the late March peak flows. The density of MADCR HWMs following the mid-March peak flows ranged from a lower quartile of about 1.0 to an upper quartile of about 2.2 , with a median of $1.1 \mathrm{HWMs}$ per mile. 


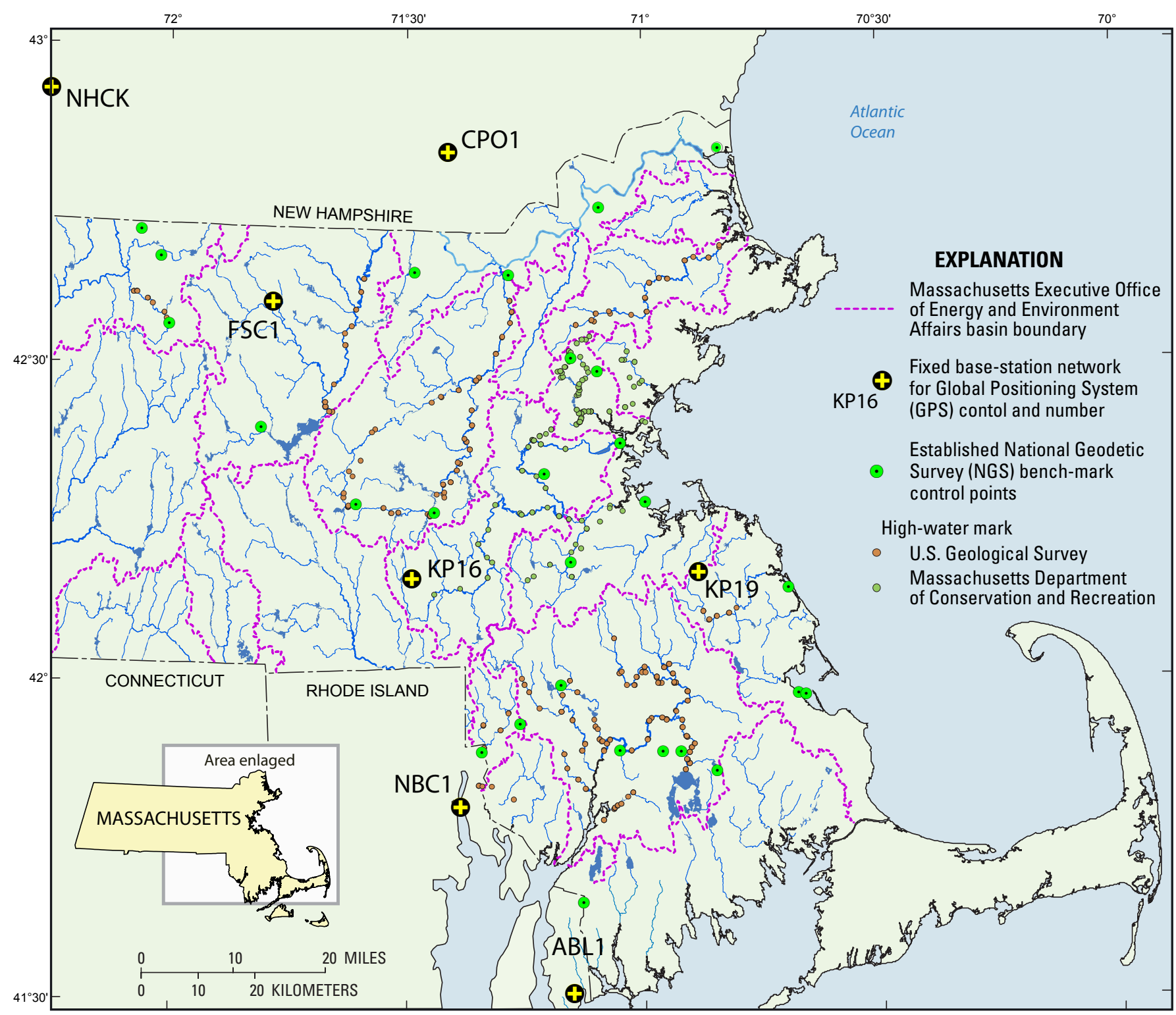

Base from Massachusetts Executive Office of Energy and Environmental Affairs digital data;

HYDRO25K_ARC , 1,25,000, 2005; MAJPOND_POLY, 1:100,000, 1998; SUBBASINS_POLY, 1:25,000,2007;

Polyconic projection. North American Datum of 1983; Massachusetts coordinate system mainland zone 1998;

Figure 6. Fixed-based station Global Positioning System receiver network and National Geodetic Survey bench-mark control points used in the determination of the elevation of the March-April 2010 flood high water in central and eastern Massachusetts. 


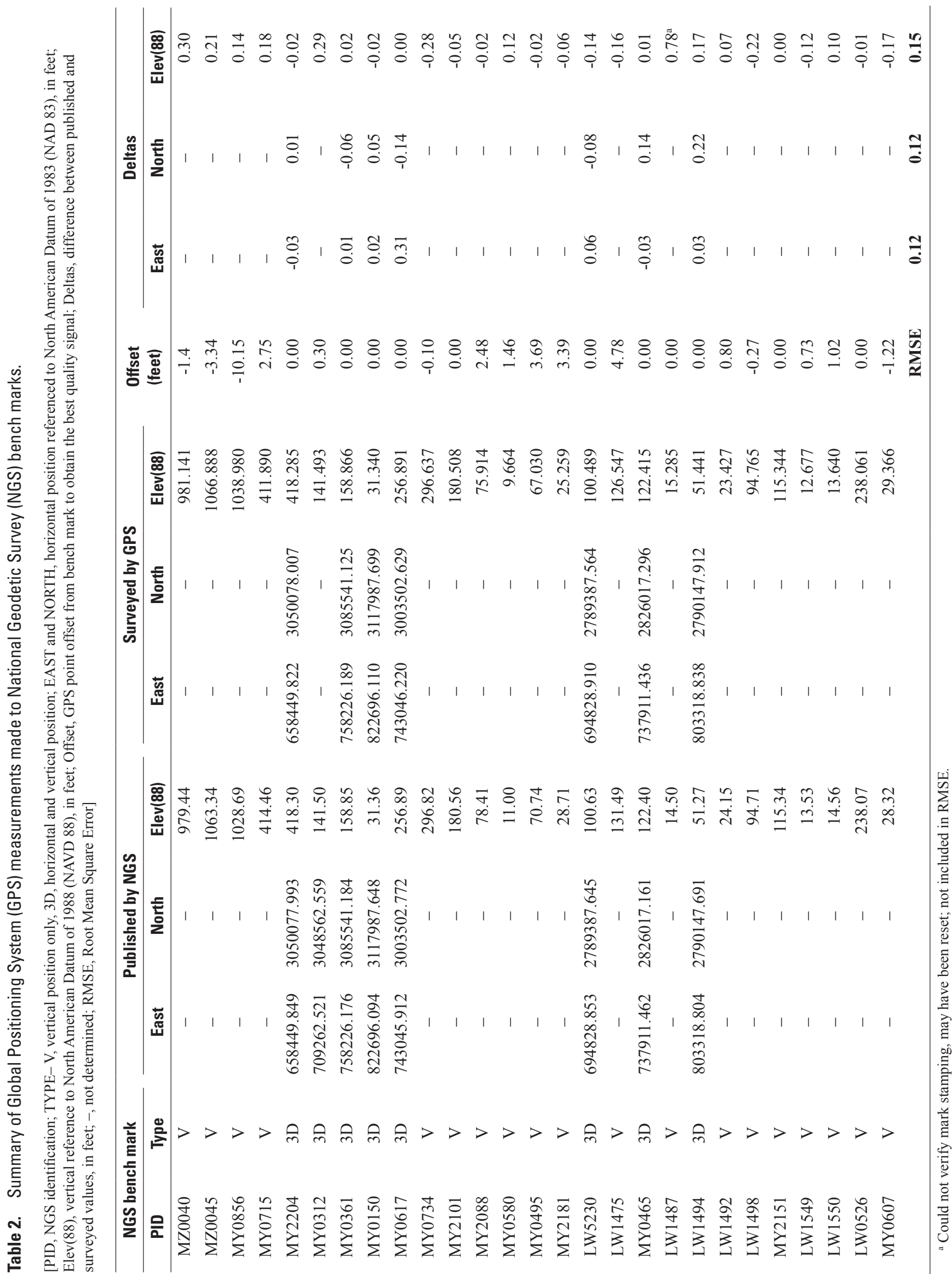


Table 3. Summary of high-water marks (HWMs) established by the U.S. Geological Survey (USGS) and the Massachusetts Department of Conservation and Recreation (MADCR) following the March-April 2010 floods in central and eastern Massachusetts.

[EEA, Massachusetts Executive Office of Environmental Affairs; HWM, high-water mark; Location, number of unique locations where HWMs were identified such as upstream and downstream from a bridge; Length, approximant reach length between the most upstream and downstream HWMs; Bk, brook; HWMs and EEA basins shown in figure 1]

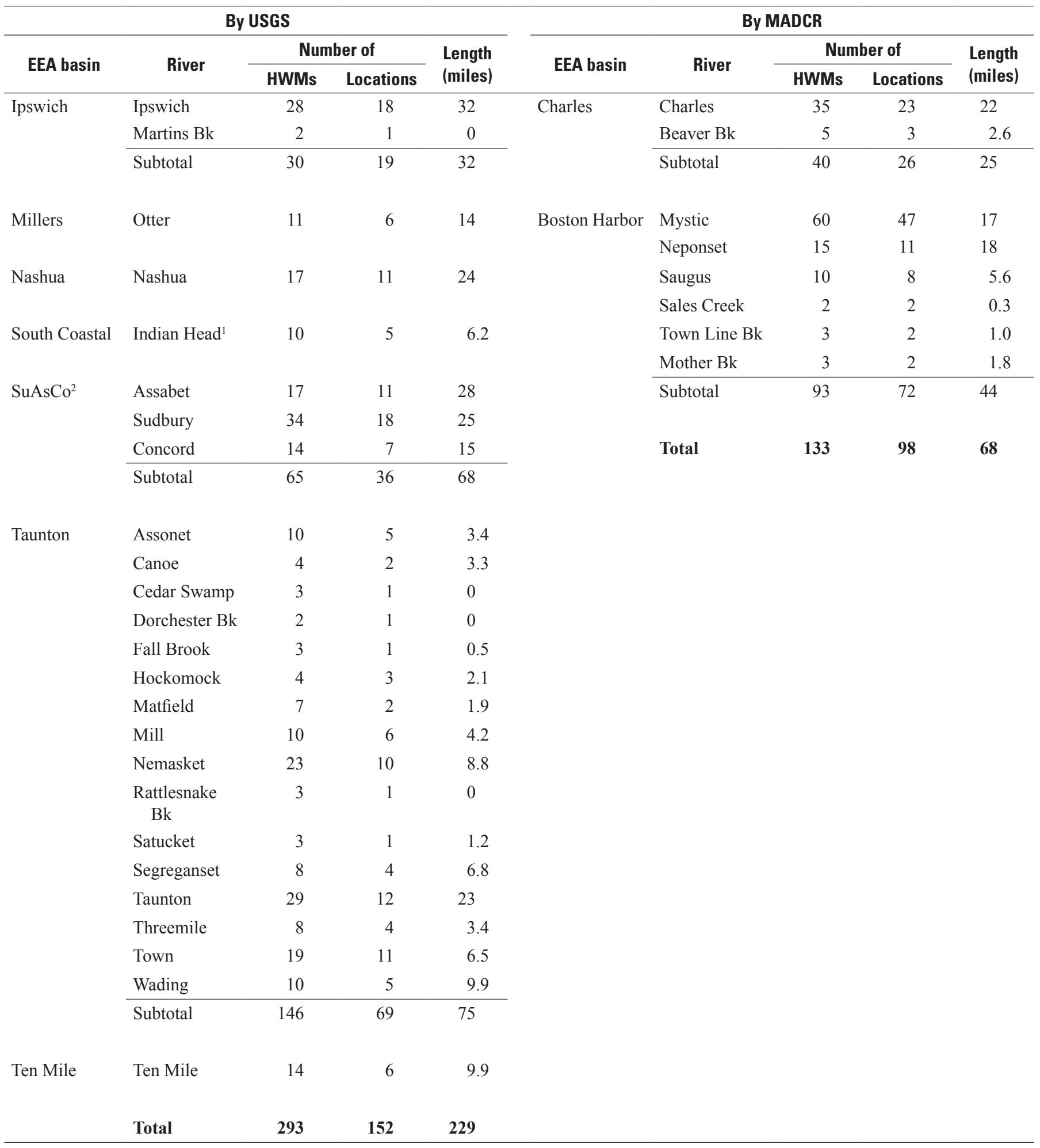

${ }^{1}$ Includes one HWM at North River, which is the name of the Indian Head River near its mouth.

${ }^{2}$ Acronym for Sudbury, Assabet, and Concord River Basins. 


\section{Potential Use of High-Water Data}

HWMs provide critical information on inundation following a flood. Mapping flood inundation is greatly enhanced by the availability of LIDAR (LIght Detection and Ranging) elevation data, which provides a high level of precision and accuracy (Gesch, 2009). The Massachusetts Office of Geographic Information (MassGIS) has twice acquired LIDAR data, once for the Boston Metro area in 2002 and again in 2004 as part of an orthoimagery and LIDAR pilot project in an area adjacent to the City of Brockton, south of Boston (fig. 7). The existing LIDAR resolution is $0.75 \mathrm{~m}$ (meter) to $1.5 \mathrm{~m}$ with a vertical accuracy of $15 \mathrm{~cm}$ (centimeter). As part of the
American Recovery and Reinvestment Act of 2009, a comprehensive LIDAR mapping program was begun in the summer of 2010 to map the coastal northeast (fig. 7) at 2-m resolution and a vertical accuracy of $15 \mathrm{~cm}$ (Smith and other, 2010).

The LIDAR data generated by this program is not expected to be completed until September 2011. When the LIDAR data become available, the HWM elevations determined in this study can be used to define the extent and depth of flooding in the selected reaches. The new LIDAR data are expected to provide complete coverage of the Taunton, Ten Mile, South Coastal, and North Coastal Basins. The lower Ipswich Basin probably will be covered by the new LIDAR data, but other areas where HWMs exist, such as the SuAsCo, Nashua, Millers, and upper Charles Basins, will still lack LIDAR data.

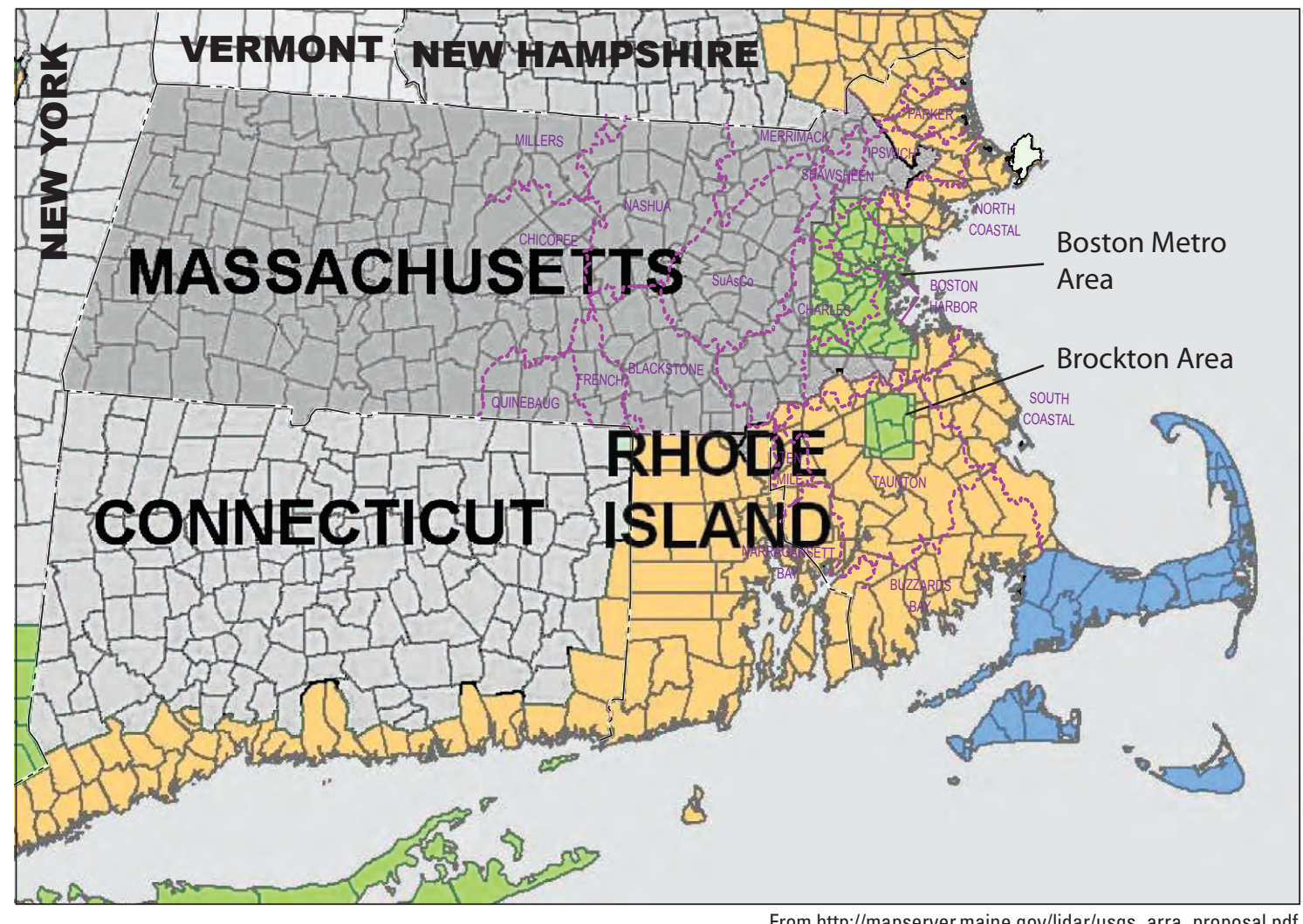

EXPLANATION

Existing LIDAR data

LIDAR data planned for aquistion in 2010-2011

FEMA planned LIDAR data aquistion in 2010-2011

Massachusetts Executive Office of Energy and

Environment Affairs basin boundary and name

Figure 7. Areas of availability of LIght Detection and Ranging (LIDAR) data and projected 2011 LIDAR data in Massachusetts and adjacent states. 


\section{Summary}

A series of widespread, large, low-pressure systems in southern New England in late February and in mid- through late March resulted in record, or near record, amounts of rainfall. The late February storm dropped nearly 5 inches of rain over the region that primed conditions for triggering the first large flood that followed the 4 to 9 inches of rain that fell between March 13 and 15, 2010. As flood waters began to recede, 2 to 5 inches of rain fell on March 22-23, maintaining wet conditions and elevating streamflows over the region. This was followed by another storm on March 29-30. The total rainfall in central and eastern Massachusetts from late February to the end of March 2010 ranged from about 17 to 25 inches, which is unprecedented in the past 100-year weather history, especially during the cool season when moisture losses to evaporation are low.

Record total rains during late February and March resulted in peak stream stages and flows that set, or nearly set, period-of-record peaks at streamgages in central and eastern Massachusetts. Streamgages in southeastern Massachusetts indicated the highest peak stages and flows generally occurred in late March-early April; at most other streamgages in central and eastern Massachusetts, the primary peaks were in mid-March. The mid-March peak flows were as little as 1 percent greater than the late March-early April peaks in the Assabet and Concord Rivers, but the differences between the mid-March peak flows and the late March-early April peak flows generally increased to the west and north of southeastern Massachusetts. In rivers and streams where the mid-March peak stages were higher than the secondary peak stages in late March-early April, the determination of the HWM was less certain because evidence of the earlier peaks may have been destroyed.

Identification of HWMs by the USGS began on April 13 and continued through May 10, 2010. Because identification of HWMs by the USGS did not begin until mid-April, field crews sometimes found two distinct high-water lines that likely resulted when the late March-early April peak was lower than the mid-March peak. The topmost evidence of high water was used when establishing a HWM, but if the overall peak occurred in mid-March, evidence of that peak could have been erased by heavy rains in late March. The MADCR marks were made shortly after peak flows in midMarch and again in March-early April by a consultant for MADCR.

The elevation of HWMs were later determined to a standard vertical datum (NAVD 88) using the Global Navigation Satellite System and survey grade Global Positioning System (GPS) receivers along with standard optical surveying equipment. Continuous real-time differential corrections to the GPS positions were made using a proprietary fixed-base station network. Quality-assurance GPS measurements made at 26 established National Geodetic Survey bench marks (BMs) with vertical datum throughout the study area (fig. 1) yielded a vertical root mean square error of $0.15 \mathrm{ft}$.
HWMs following the March 2010 floods were obtained for 25 river reaches in 7 designated EEA basins by the USGS and for 8 river reaches in 2 designated EEA basins by MADCR. The USGS identified $293 \mathrm{HWMs}$ at 152 sites. A site may have more than one HWM, typically a bridge crossing with HWMs identified on the upstream and downstream sides of the bridge. The MADCR identified 133 HWMs; of these, 98 are at unique locations, and 29 were visited twice following the mid-March peaks and again after the late March peaks. The HWMs identified by the USGS and MADCR covered about 300 river miles (about 230 and 70 river miles, respectively), as determined from the upstream and downstream HWMs along a reach.

\section{Acknowledgments}

Identification of HWMs was made by USGS personnel from Water Science Centers in Massachusetts-Rhode Island (Robert Breault, Gene Parker, Mark Nimiroski, and Andy Waite), Connecticut (Elizabeth Ahearn, Karen Beaulieu, Jonathon Morrison, and Jason Pollander,) and Maine (Pamela Lombard, Nicholas Stasulis, and Greg Stewart). HWMs made for MADCR were supplied by Richard Zingarelli. Survey of HWMs was made by personnel from USGS Water Science Centers in Massachusetts-Rhode Island (Paul Friesz, Gene Parker, Andy Massey, and Andy Waite) and Ohio (Carrie Huitger, Jonathon Lageman, Chad Ostheimer, and Matthew Whitehead).

\section{References Cited}

Benson, M.A., and Dalrymple, Tate, 1967, General filed and office procedures for indirect discharge measurements: U.S. Geological Survey Techniques of Water-Resources Investigations, book 3, chap. A1, $30 \mathrm{p}$.

FEMA-Federal Emergency Management Agency

FEMA, 2003, Guideline and specifications for flood hazard mapping partners, Appendix A: Guidance for aerial mapping and surveying, Federal Emergency Management Agency, 59 p., accessed August 6, 2010, at: http://www. fema.gov/library/viewRecord.do?id $=2206$

FEMA, 2010, Bay state assistance tops $\$ 100$ million; Disaster recovery update, released August 17, 2010, accessed August 25, 2010, at http://www.fema.gov/news/newsrelease. fema? id $=52380$

Gesch, D.B., 2009, Analysis of Lidar elevation data for improved identification and delineation of lands vulnerable to sea-level rise: Journal of Coastal Research, SI 53 p. 49-50, accessed August 26, 2010, at http://topotools. cr.usgs.gov/pdfs/jcr_gesch_SI53.pdf 
Northeast Regional Climate Center (2010), New England Climate, March 2010, v. 110, no. 3, accessed July 26, 2010, at http://www.nrcc.cornell.edu/pubs/msmry_ne_2010-03.pdf

Smith, Michael; Rubin, Fay; Jacqz, Christian; White, Shane; Varney, Michael; and Ruhren, Tim, 2010, Lidar for the northeast, Maine Office of GIS, 109 p., accessed August 25, 2010, at http://mapserver.maine.gov/lidar/usgs_arra_ proposal.pdf

U.S. Department of Commerce, 1955, Climatological data New England, August 1955, Weather Bureau, V. LXVII, no. 8, 20 p., accessed October 26, 2010, at $h t t p: / / w w w 7$. ncdc.noaa.gov/IPS/cd/cd.html? page $=0 \& j$ sessionid $=A 5$ 0481FDDB5BC9A82BAC9B6604E51C59\&state $=$ MA\&_ target $1=$ Next 
(This page intentionally left blank.) 
Appendix 


\section{Appendix 1. High-water marks identified by the U.S. Geological Survey and the Massachusetts Department of Conservation and Recreation}

Note, most of the information contained in the tables can be obtained electronically in a geographical information system format (shape file) at http://pubs.usgs.gov/ofr/2010/1315/.

- Table 1-1. High-water marks identified by the U.S. Geological Survey following the March-April 2010 floods in central and eastern Massachusetts.

- Table 1-2. High-water marks identified by the Massachusetts Department of Conservation and Recreation following the March-April 2010 floods in eastern Massachusetts. 


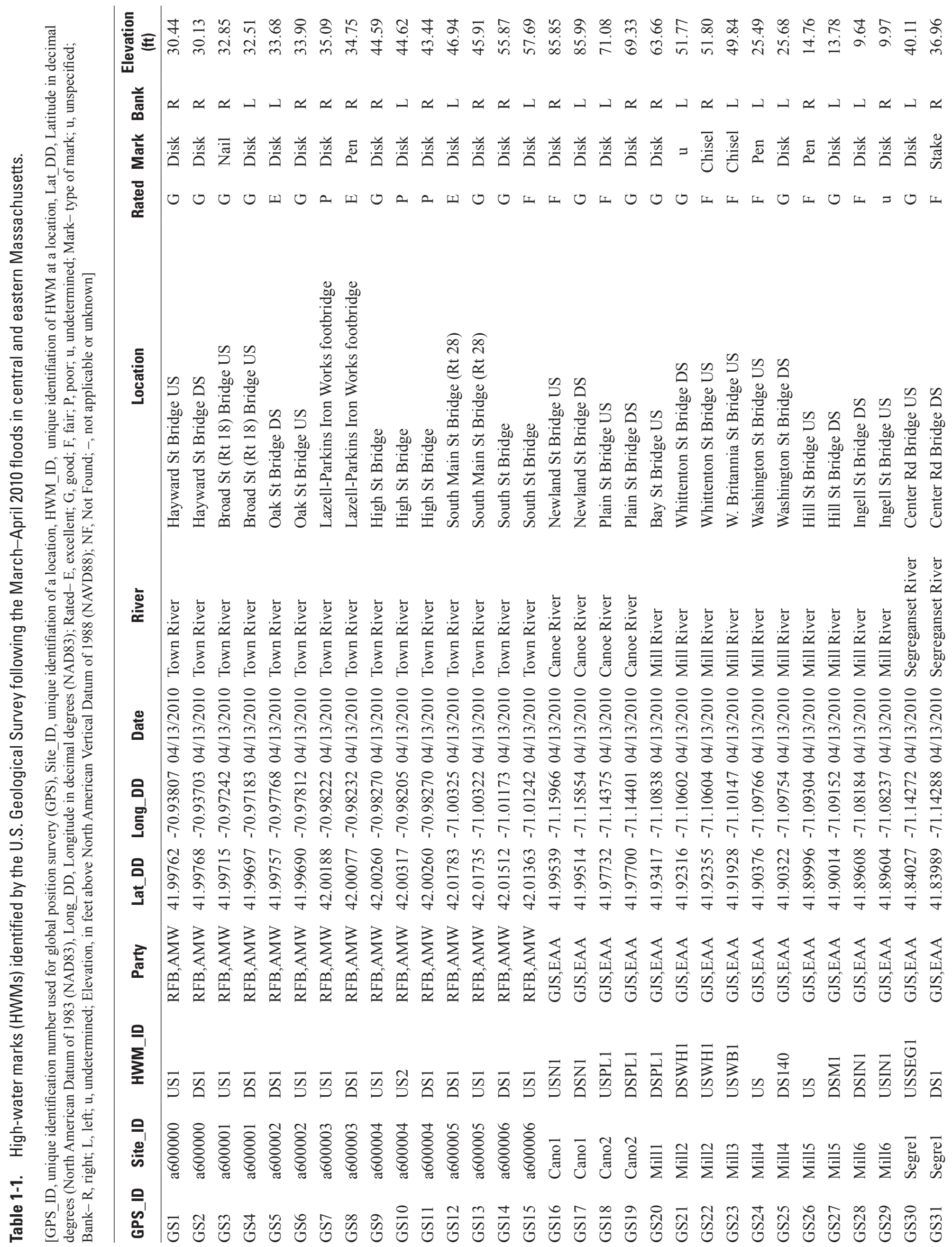




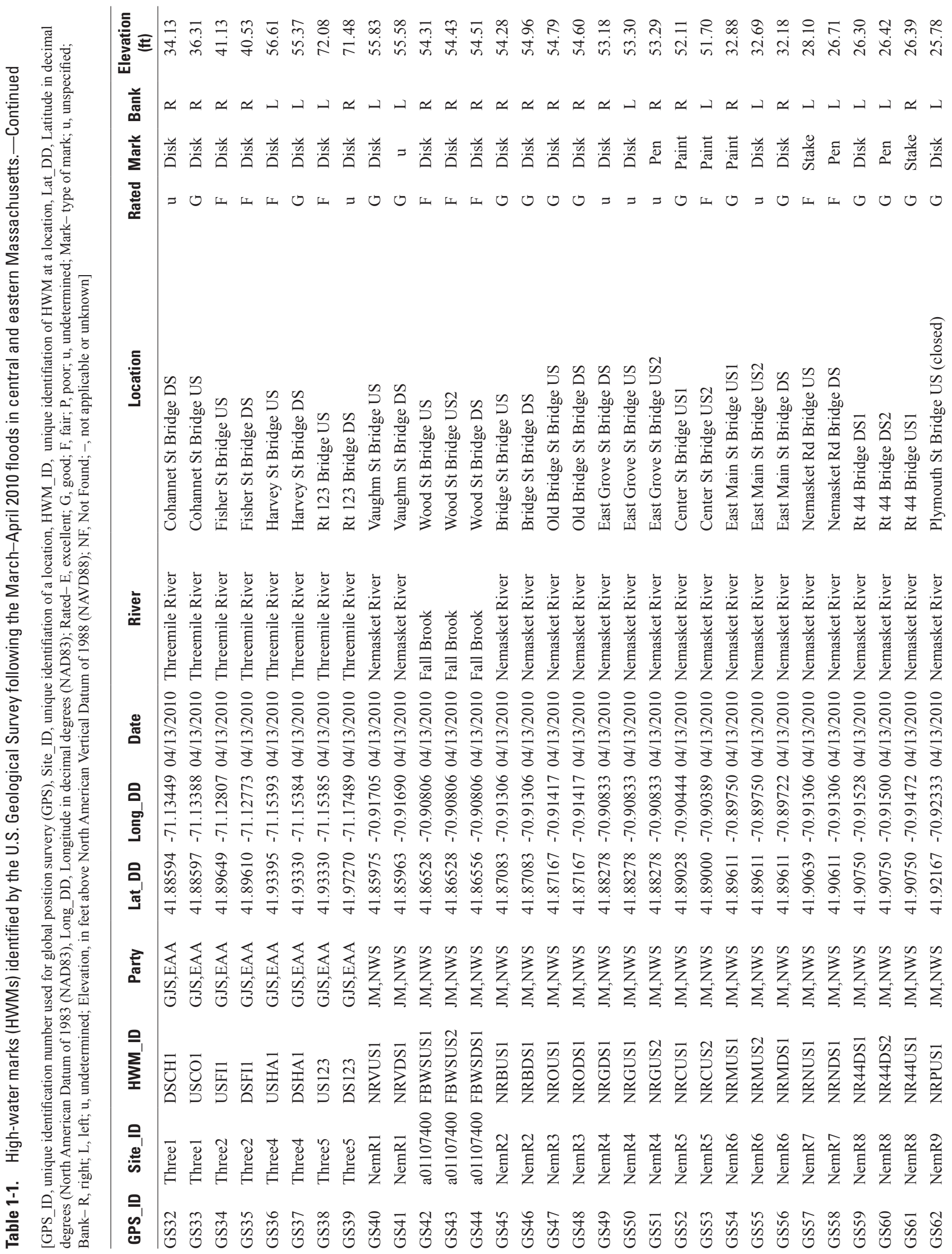




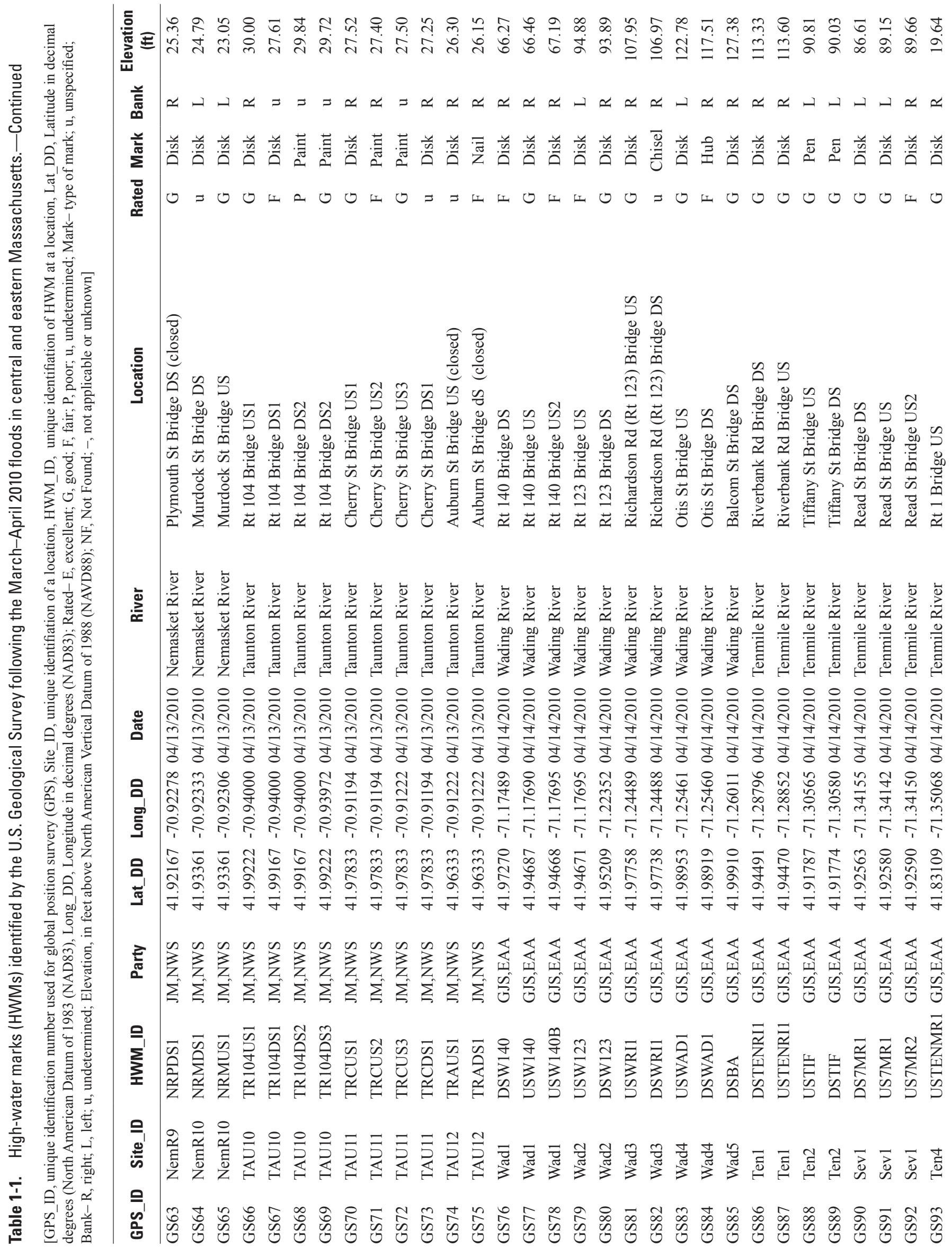




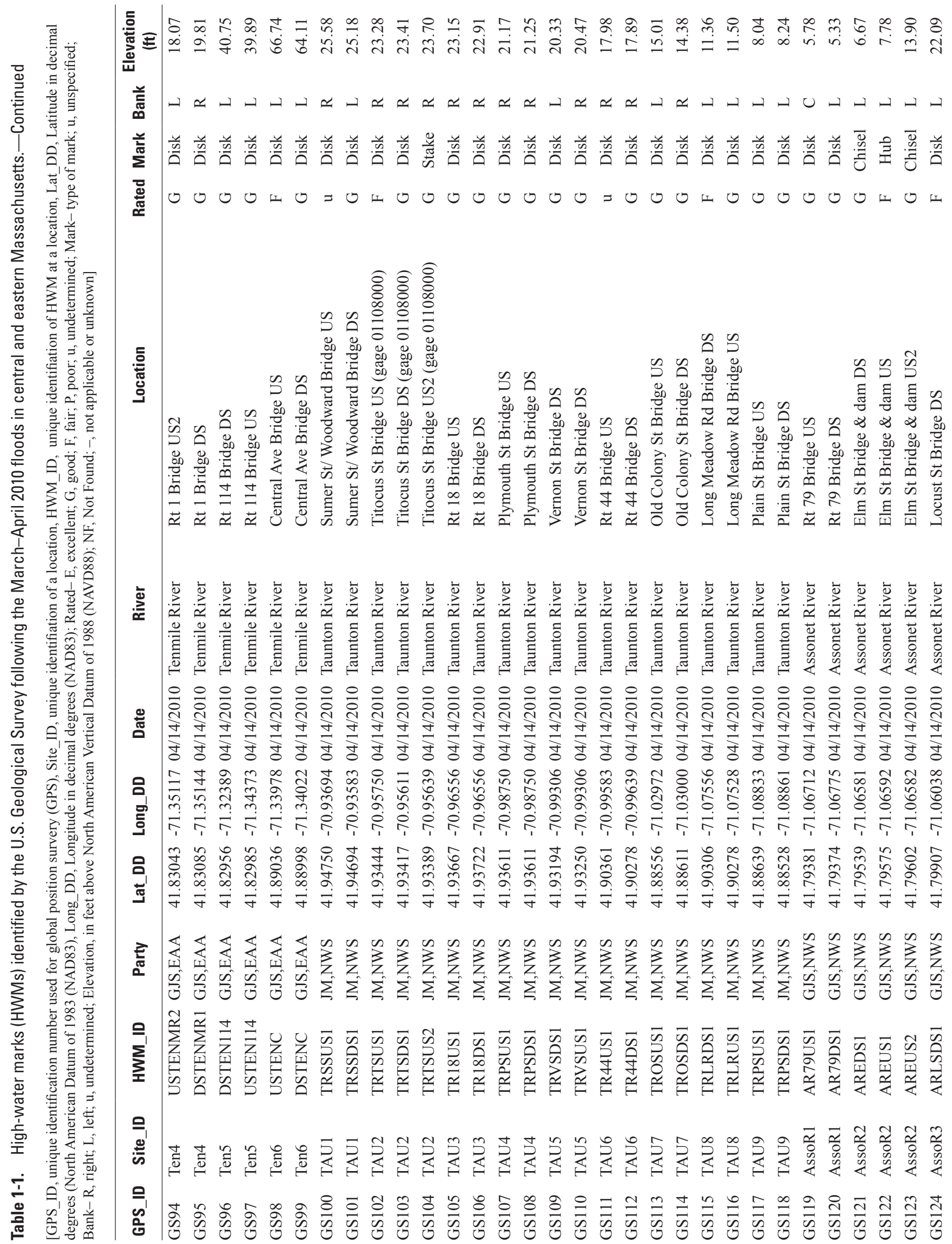




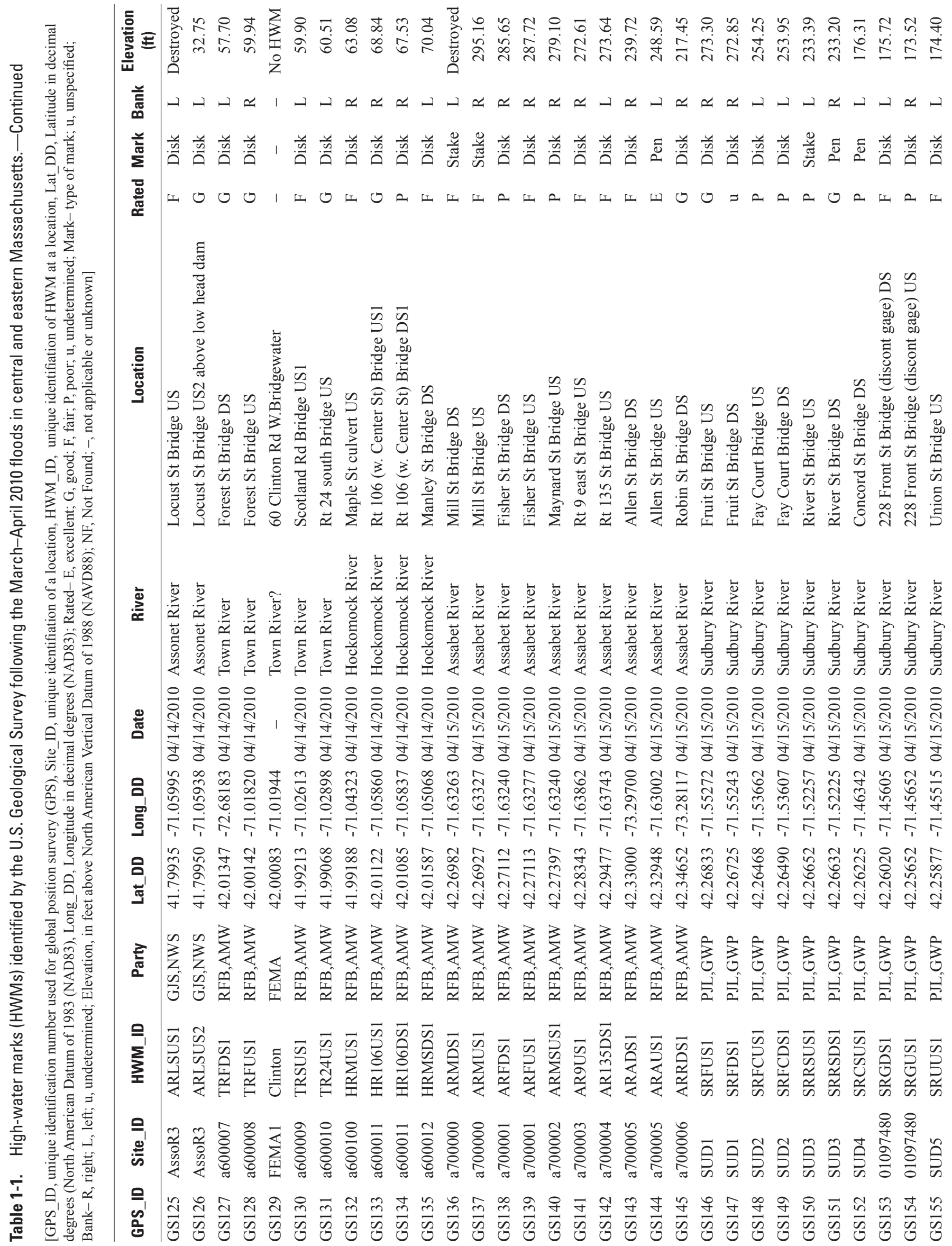




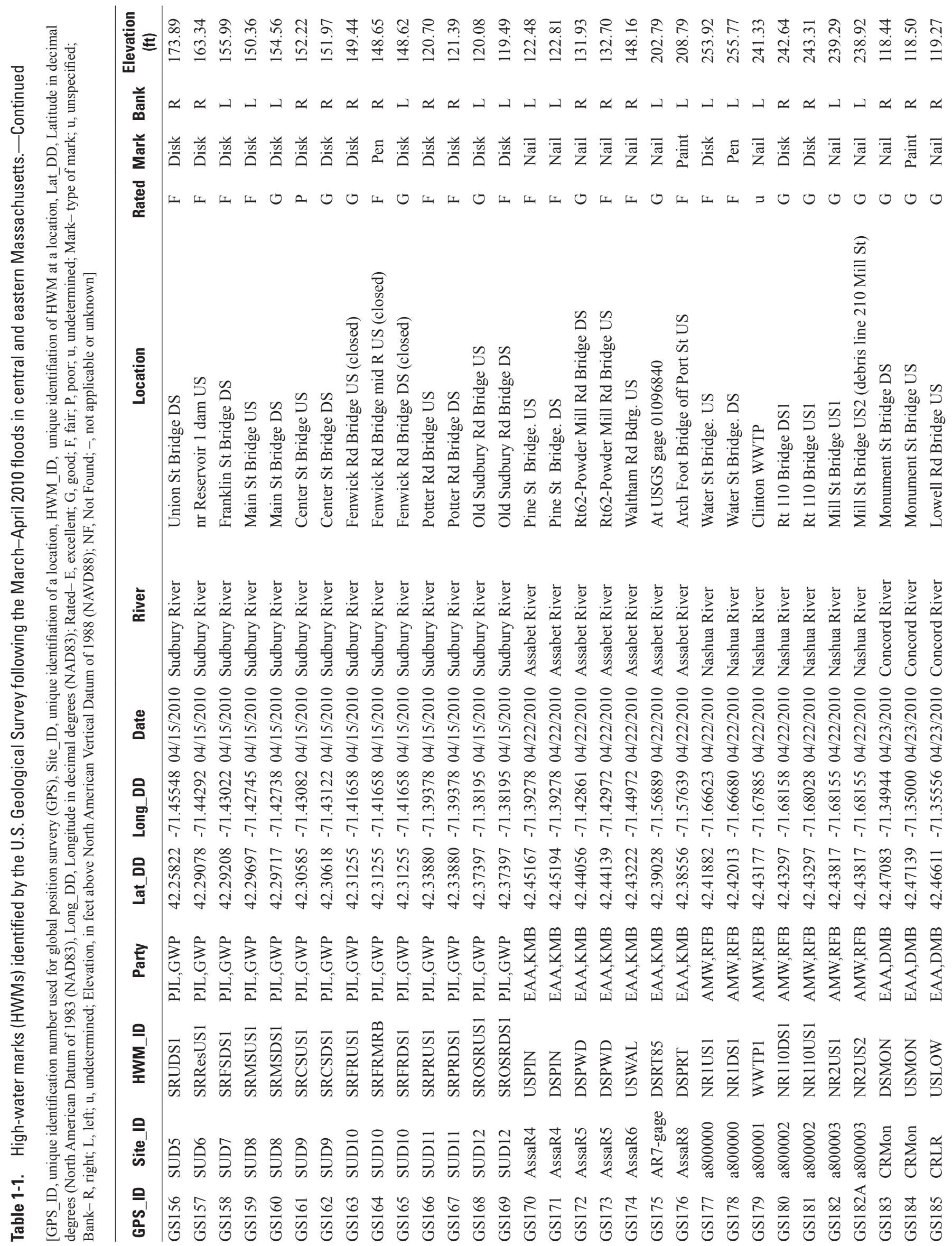




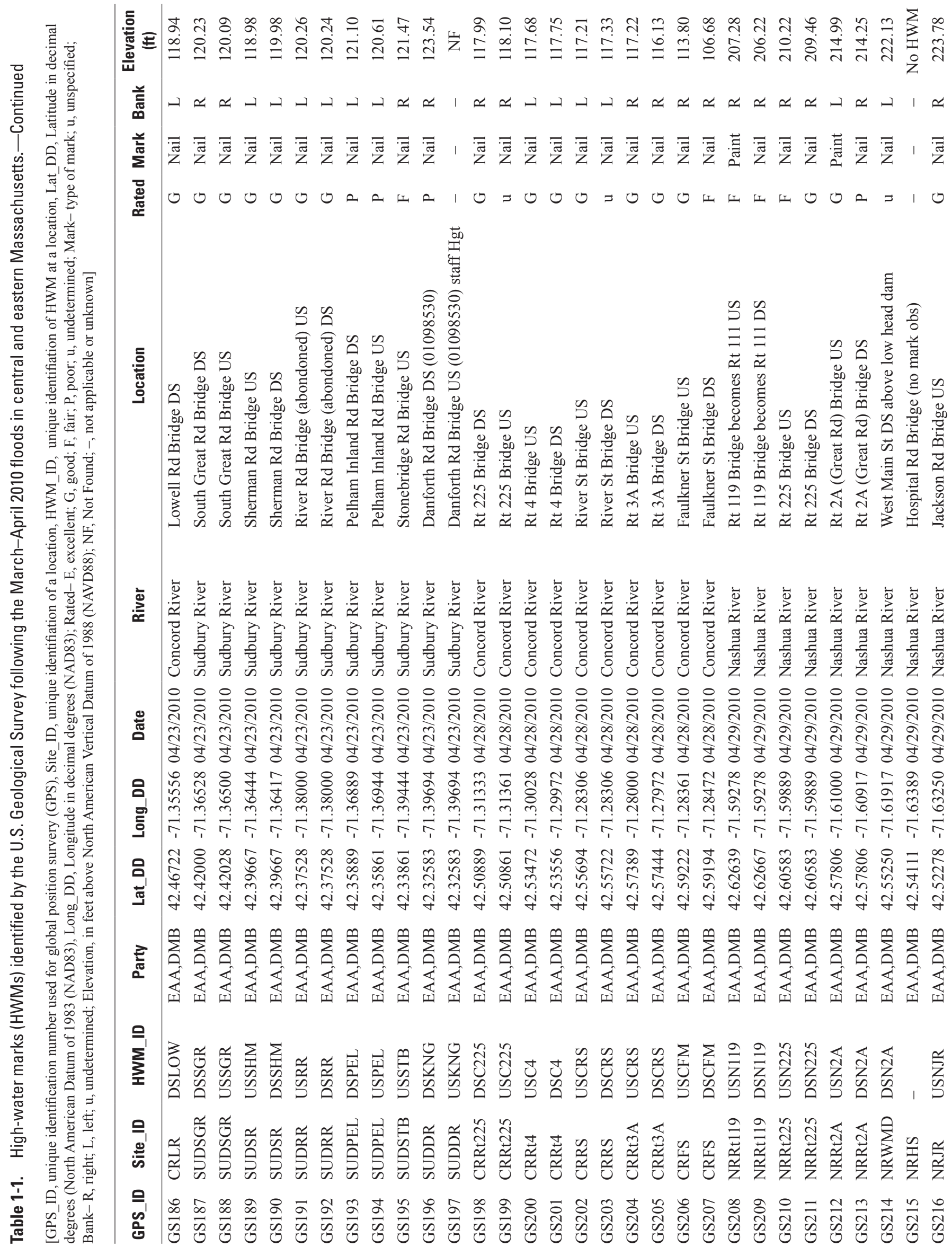




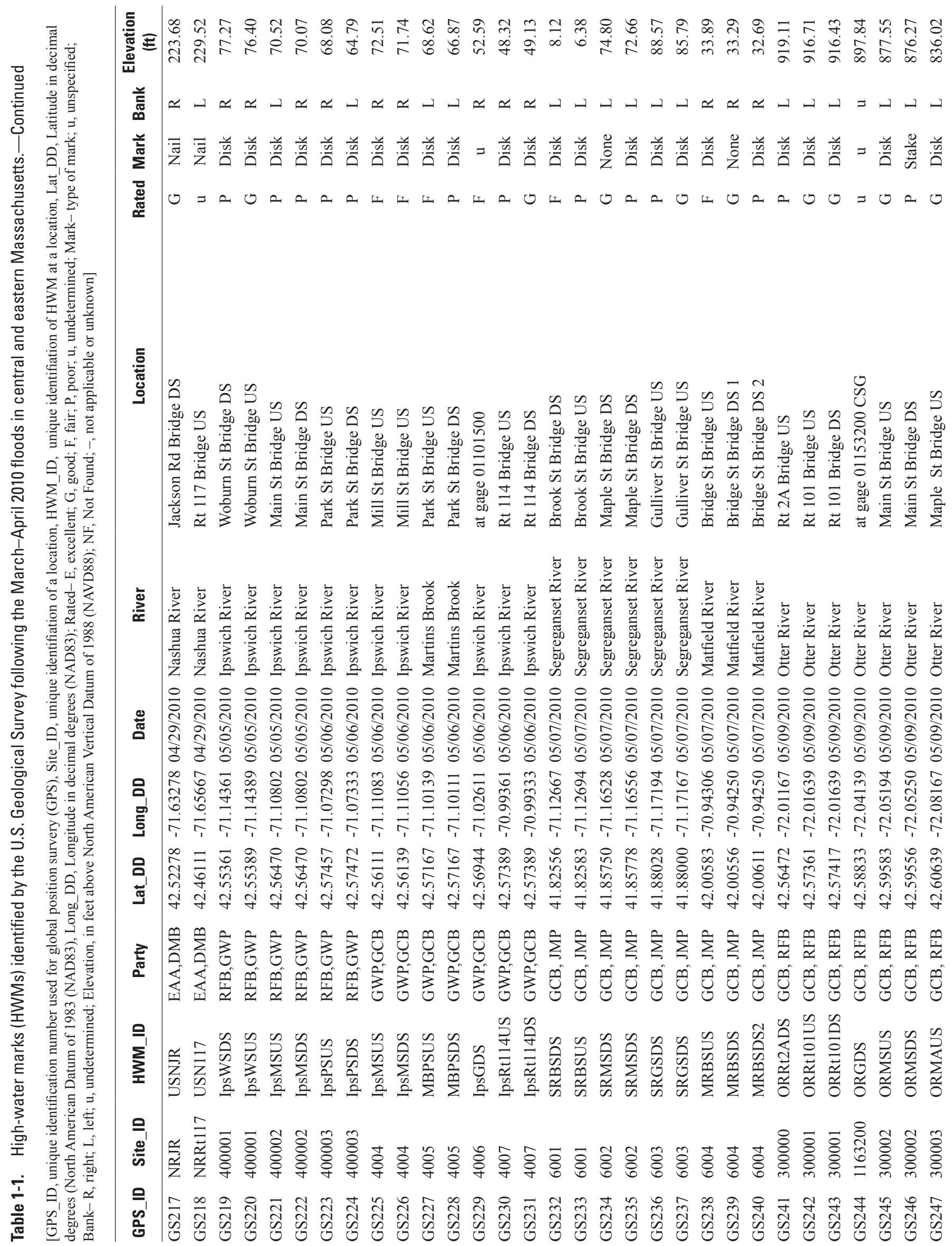




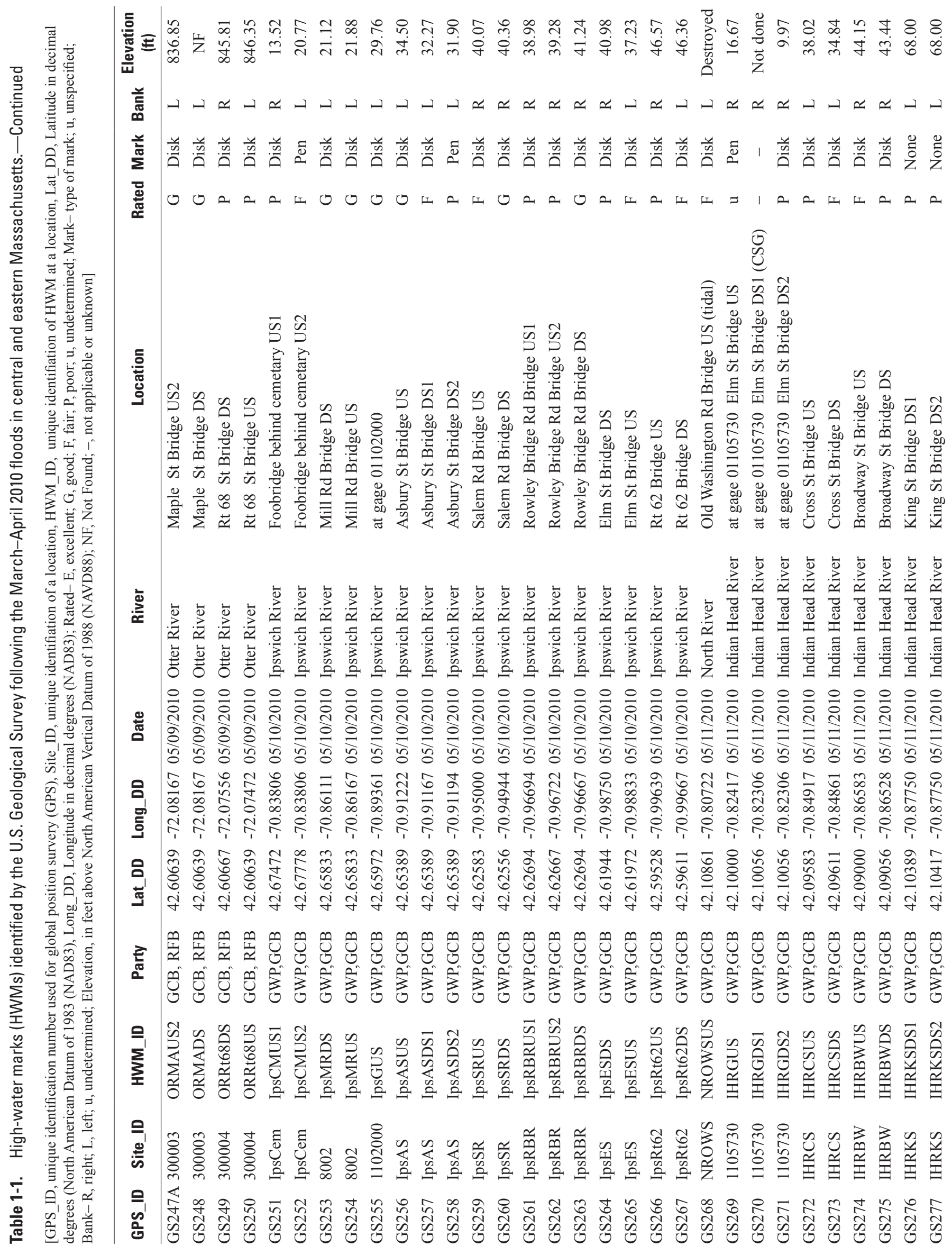




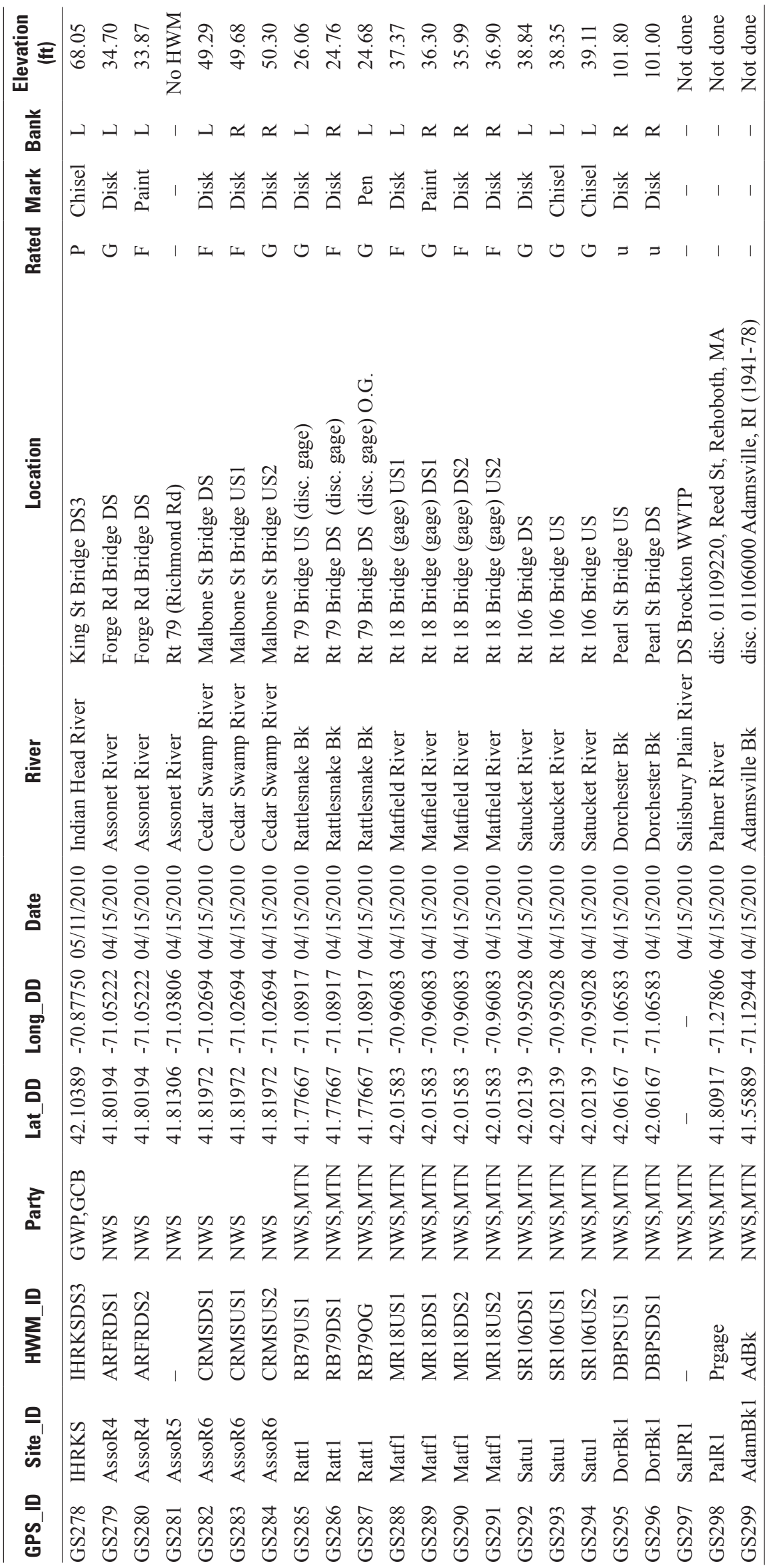




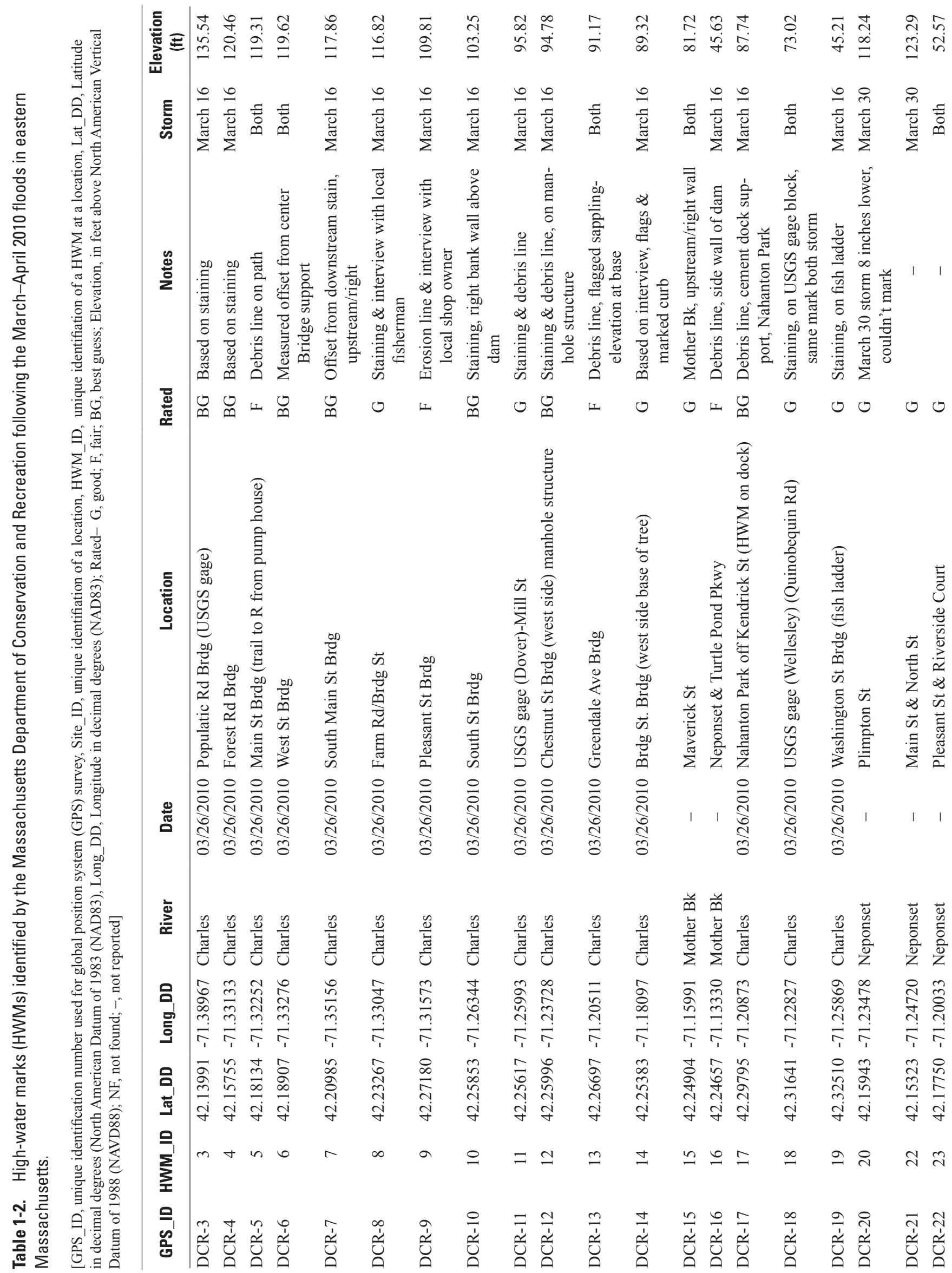




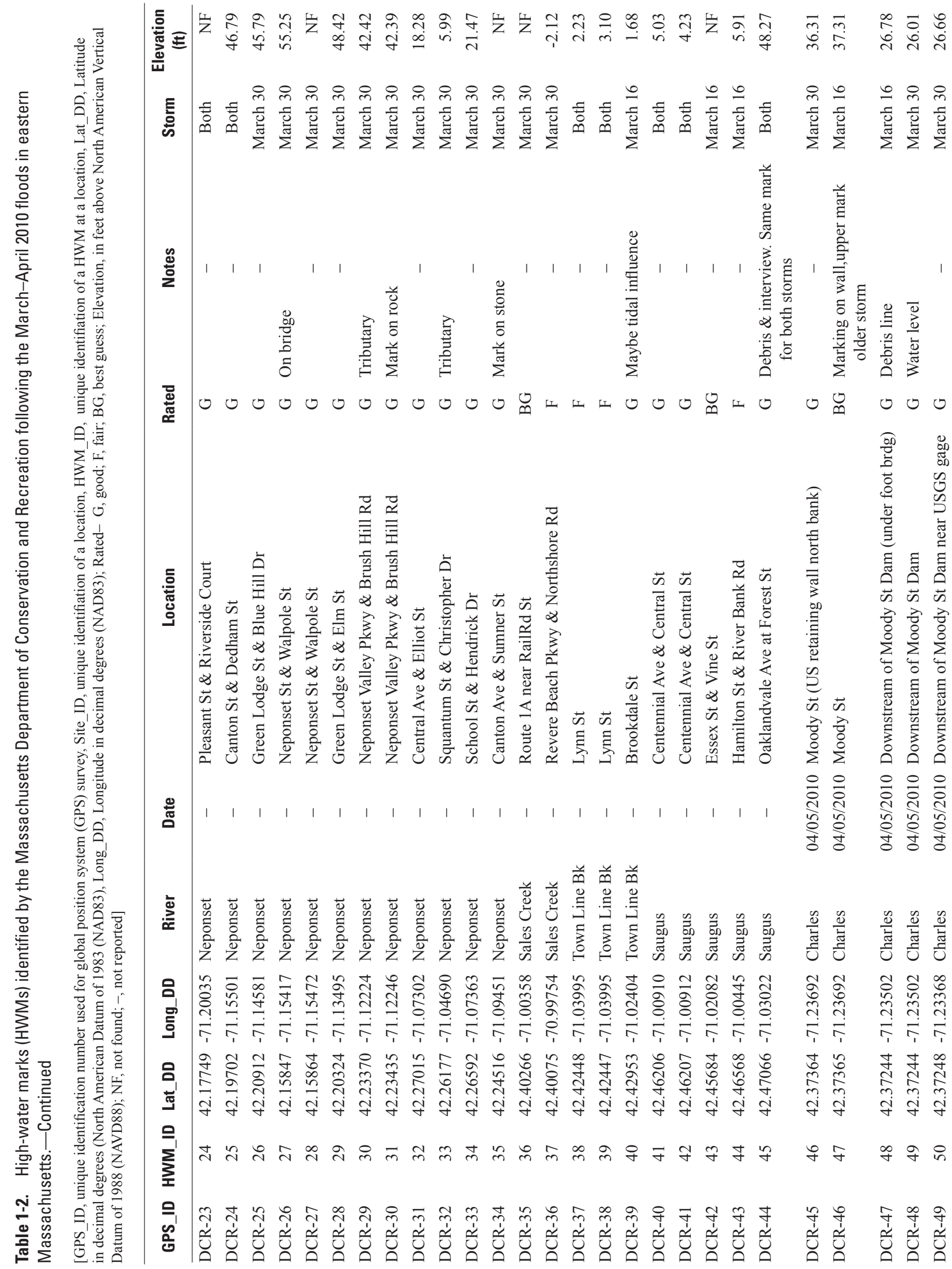




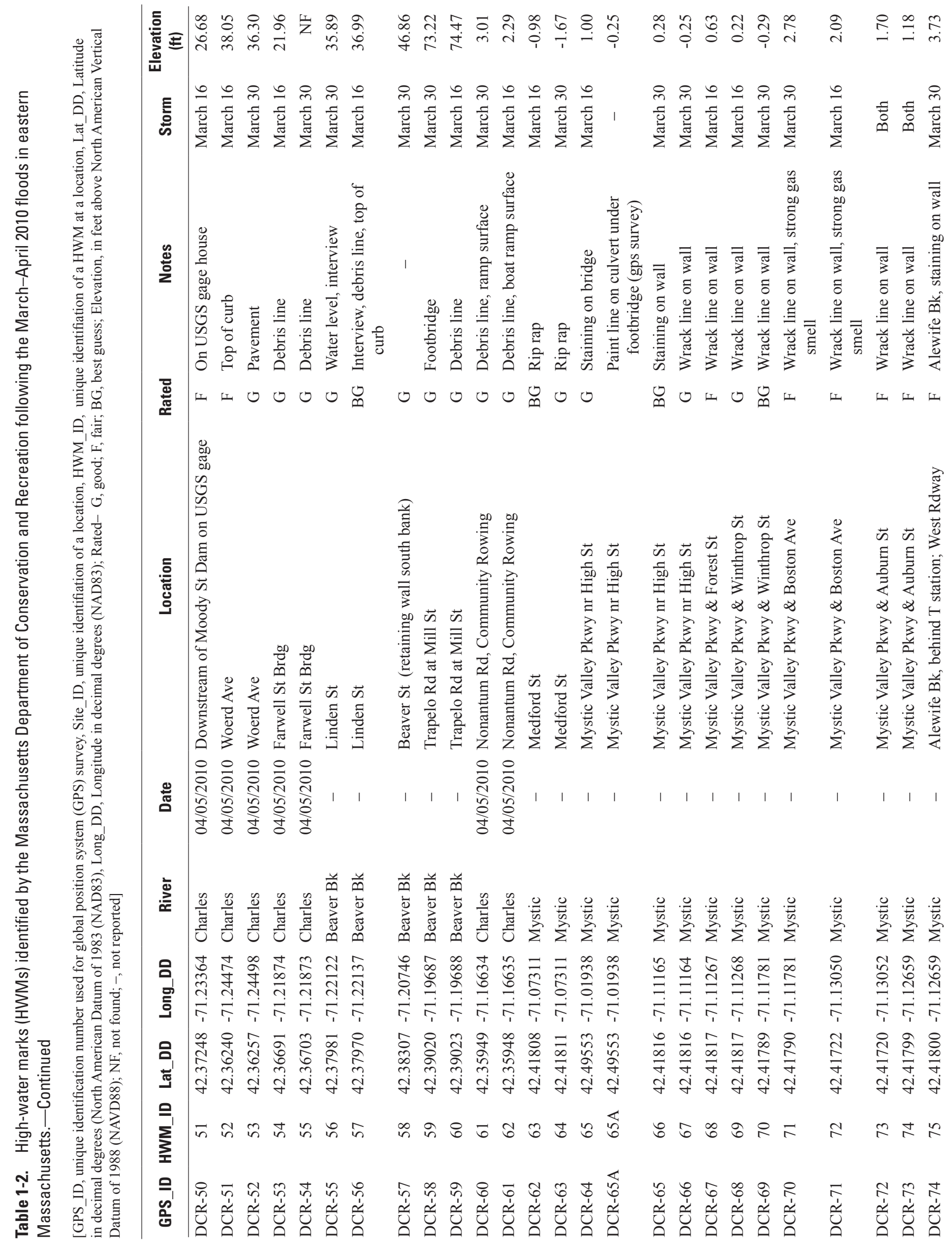




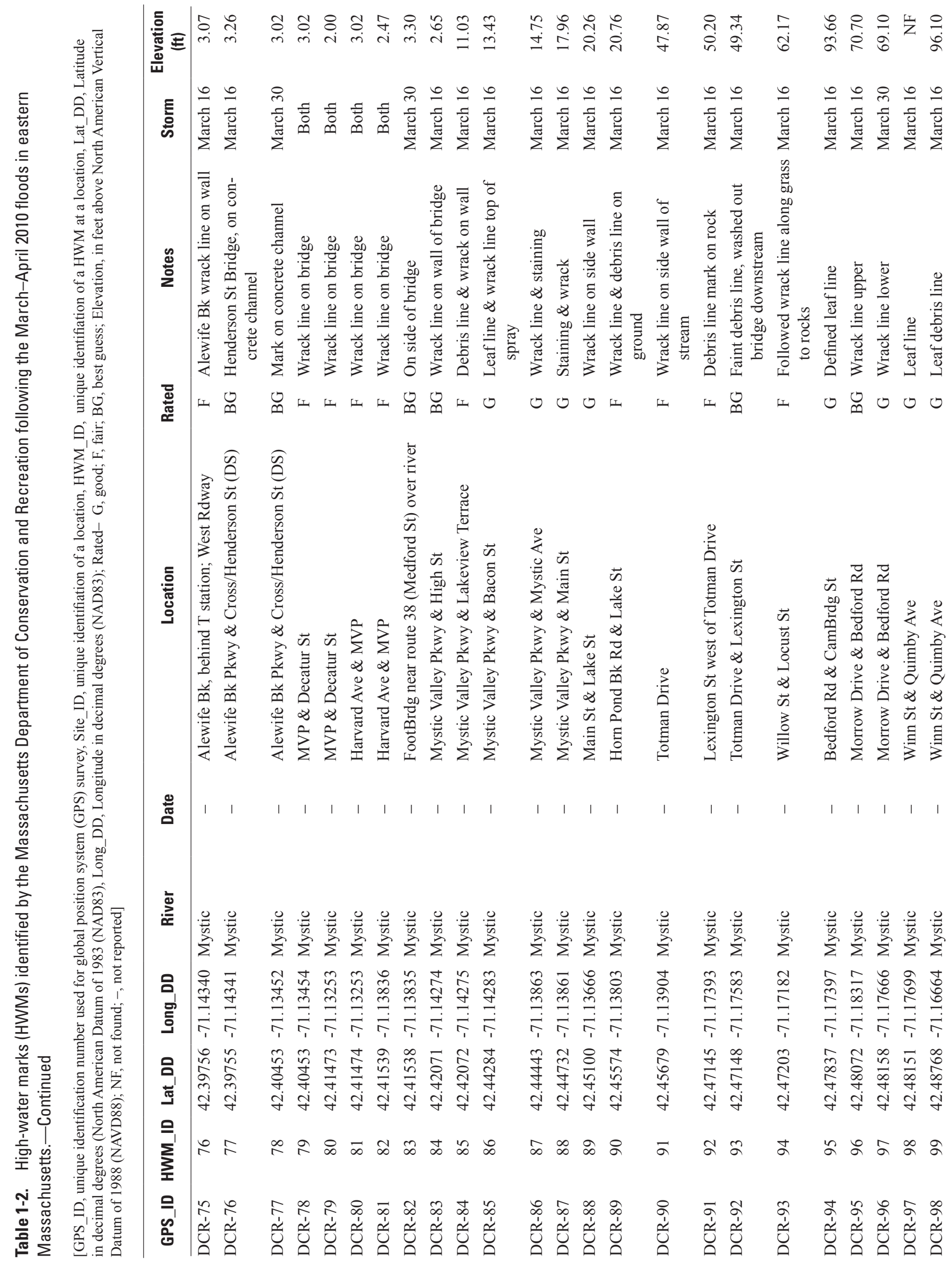




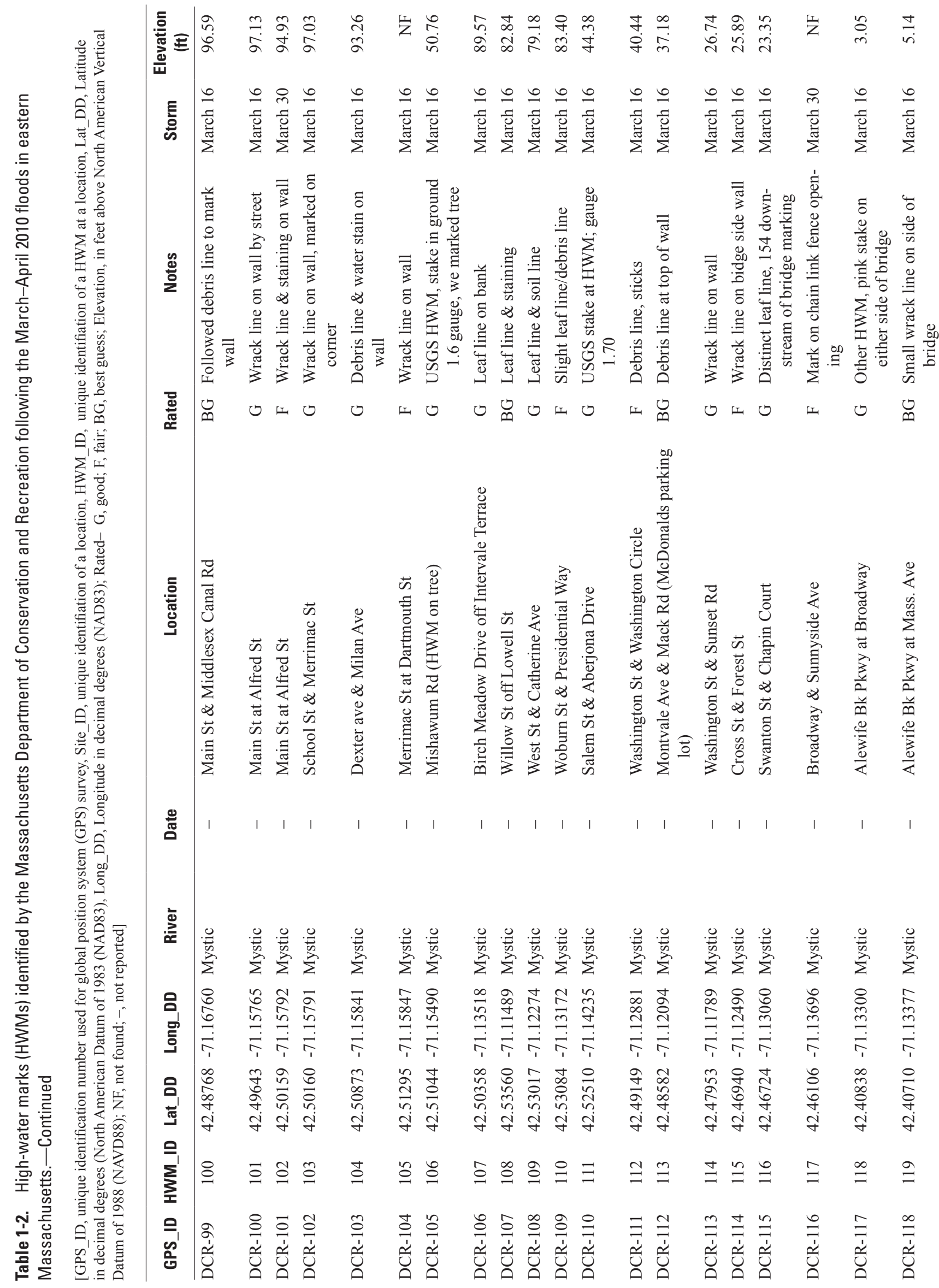




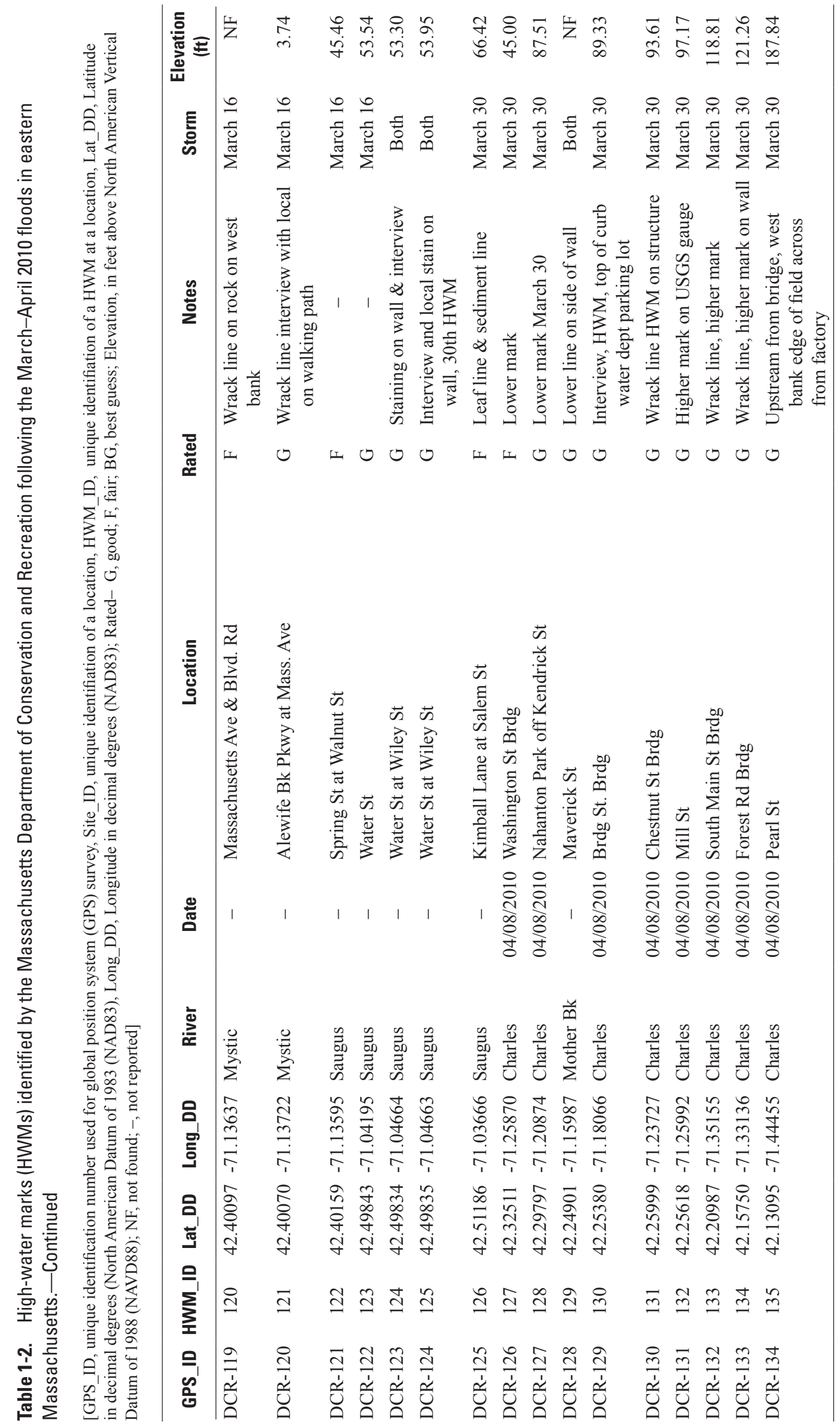


For additional information, write to:

Director

U.S. Geological Survey

Massachusetts Water Science Center

10 Bearfoot Road

Northborough, MA 01532

or visit our Web site at:

http://ma.water.usgs.gov/

Document prepared by the Pembroke and West Trenton Publishing Service Centers 


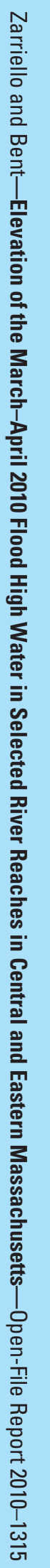

8 Printed on recycled paper 